\title{
MACROECONOMIC STABILITY: TRANSITION TOWARDS THE NOMINAL EXCHANGE RATE STABILITY
}

\author{
František Brázdik \\ Juraj Antal
}
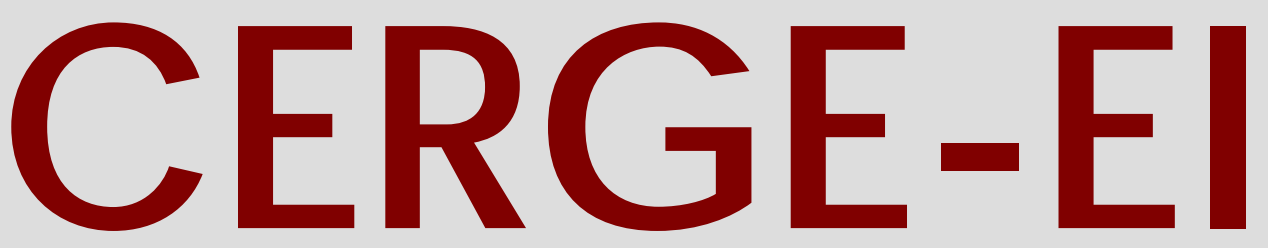

Charles University Centerfor Economic Research and Graduate Education Academy of Sciences of the Czech Republic Ec onomic s Institute 


\section{Working Paper Series 368 (ISSN 1211-3298)}

\section{Macroeconomic Stability: Transition Towards the Nominal Exchange Rate Stability}

František Brázdik

Juraj Antal

CERGE-EI

Prague, October 2008 
ISBN 978-80-7343-168-6 (Univerzita Karlova. Centrum pro ekonomický výzkum a doktorské studium)

ISBN 978-80-7344-157-9 (Národohospodářský ústav AV ČR, v.v.i.) 


\title{
Macroeconomic Stability: Transition Towards the Nominal Exchange Rate Stability*
}

\author{
František Brázdik Juraj Antal
}

$\check{\mathrm{CNB}}^{\dagger}$ and $\mathrm{CERGE}-\mathrm{EI}^{\ddagger}$

October 2008

\begin{abstract}
The novelty of this work is in the presentation of a theoretical framework that allows the modeling of an announced switch of the monetary regime. In our experiment, the monetary authority announces stabilization of the nominal exchange rate after the announced number of periods. We analyze the effects of the monetary policy regime for the macroeconomic stability over the transition period. For our analysis, we consider representative forms of standard monetary regimes. Moreover, we rank the examined regimes in terms of loss functions.
\end{abstract}

\begin{abstract}
Abstrakt
Přínosem práce je prezentace teoretického přístupu $\mathrm{k}$ modelování ohlášené změny monetárního režimu. V experimentu monetární autorita dopředu vyhlásí přechod na nový režim s cílem stabilizace kurzu. Dále je pomocí vybraných reprezentativních případů analyzován vliv volby měnového režimu v období přechodu. Tyto režimy jsou srovnávány pomocí funkce ztráty užitku.
\end{abstract}

Keywords: New Keynesian Models, Small Open Economy, Monetary regime switch

JEL classification: E17, E31, E52, E58, E61, F02, F41

${ }^{*}$ The views expressed in this article are those of the authors and do not necessarily reflect those of the Czech National Bank.

${ }^{\dagger}$ Czech National Bank, Economic Research Department. Address: ČNB, Na Př́́kopě 28, Praha 1, 115 03, Czech Republic

$\ddagger$ A joint workplace of the Center for Economic Research and Graduate Education, Charles University, Prague, and the Economics Institute of the Academy of Sciences of the Czech Republic. Address: CERGE-EI, P.O. Box 882, Politických vězňů 7, Prague 1, 111 21, Czech Republic 


\section{Introduction}

New members of the European Union agreed to join the European monetary union (EMU) in the accession treaty. To achieve this goal, countries with an independent monetary policy have to demonstrate that they are able to fulfill economic stability requirements. Therefore, monetary union applicants have to demonstrate their stability under the expectations of common currency adoption over the transition period. Over the considered transition period; countries are able to run independent monetary policy that supports macroeconomic stability measured as the variance of economic indicators (inflation, output and interest rate).

An important issue is how the announcement of adopting such a regime affects macroeconomic stability of the small open economy. For instance, how will the outcome of monetary policy differ when the expectations are driven by a future regime? Will the macroeconomic stability increase over the transition regime? How will the loss originating from the expectations of the regime switch evolve?

We focus on the behavior of a small open economy that announces its plan to adopt such a future monetary regime that suppresses deviations in the nominal exchange rate. The considered monetary regime is defined so that its only objective is to off-set changes in the nominal exchange rate. In our experiment, monetary authority also announces the time of the regime switch and chooses transitory period regime from the given set of regimes. The examined set of regimes includes various flexible exchange rate regimes and a regime focused on exchange rate stability. However, we do not question the optimality of used regimes. As in Cuche-Curti, Dellas, and Natal (2008), we also believe that conducting an optimal monetary policy is limited by informational problems. Therefore, rather than assuming unconstrained information capabilities of policy maker as optimal policy rules do, we conduct our analysis by comparing simple monetary regimes.

The goal of a transitory period regime is to support the macroeconomic stability of the independent economy over this period. As Cuche-Curti, Dellas, and Natal (2008) summarize, flexible exchange rate regimes can perform better than peg under 
the presence of a high degree of domestic nominal frictions and an assumption of a monetary policy focused on price stability, and shocks originating mainly from abroad. Also, Dellas and Tavlas (2003) show that the pegging of the exchange rate is beneficial in the presence of rigidities. Therefore, following the results of CucheCurti, Dellas, and Natal (2008), we hypothesize that over the transition period, a monetary policy regime that reacts to the change in the exchange rate can deliver a higher degree of stability than the regimes not responding to these changes.

For our analysis, we employ a small open economy model following Justiniano and Preston (2004). This model is characterized by the presence of Calvo type nominal rigidities that lead to real disturbances. The monetary policy with a focus on inflation is conducted according to a forward looking Taylor rule. Parameters for the model are estimated for the Czech republic.

The novelty of this work is in the approach to modeling the transition period and the announced switch of regimes. As Farmer, Waggoner, and Zha (2007) summarize, recent work relies on the Markov switching processes to account for change in the policy rule. Instead of the switching process, we extend the structure of the standard model with a binary policy indicator.

The rest of the paper is organized as follows. Section 2 presents the model and description of the regime switch modeling. In section 3, we describe the procedure for the parameters estimation. Basic characteristics and properties of the model are presented in section 4, where impulse response functions are discussed. Section 5 presents the results of variance computation, and section 6 concludes. All figures can be found in the Appendix section.

\section{Model}

Our underlying model consists of a small open economy (domestic) and the rest of the world (foreign). ${ }^{1}$ The domestic economy is characterized by the existence of habit formation and nominal rigidities in the domestic and foreign good sectors. The

\footnotetext{
${ }^{1}$ The superscript ${ }^{*}$ denotes "foreign" throughout the paper.
} 
used underlying model was presented by Justiniano and Preston (2004). This model is based on the work of Gali and Monacelli (2002) and Monacelli (2005), where micro-foundations for the presented small open economy model are summarized and incomplete pass-through is discussed. The following sections sketch the derivation of the Justiniano and Preston's (2004) model. Our extension of this model with the policy indicator is presented at the end of this section.

\subsection{Households}

The considered small open economy is populated by a representative household that maximizes its lifetime utility function

$$
E_{t} \sum_{t=0}^{\infty} \beta^{t} e^{g_{t}}\left[\frac{\left(C_{t}-H_{t}\right)^{1-\sigma}}{1-\sigma}-\frac{N_{t}^{1+\varphi}}{1+\varphi}\right]
$$

where $\beta, 0<\beta<1$, is the utility discount factor; $\sigma$ and $\varphi$ are the inverse of elasticities of the inter-temporal substitution and labor supply, respectively; $N_{t}$ is total labor effort; $g_{t}=\rho_{g} g_{t-1}+\varepsilon_{t}^{g}$ is a preference shock, and $\varepsilon_{t}^{g} \sim N\left(0, \sigma_{g}^{2}\right) ; C_{t}$ is the consumption of a composite good; $H_{t}=h C_{t-1}$ is the external habit taken as exogenous by household as presented by Fuhrer (2000). In here, the parameter $h$ indexes the persistence of habit formation. The household consumes a Dixit-Stiglitz composite of home and foreign goods

$$
C_{t}=\left[(1-\alpha)^{\frac{1}{\eta}}\left(C_{t}^{H}\right)^{\frac{\eta-1}{\eta}}+\alpha^{\frac{1}{\eta}}\left(C_{t}^{F}\right)^{\frac{\eta-1}{\eta}}\right]^{\frac{\eta}{\eta-1}},
$$

where $\alpha$ is the share of imported goods in domestic consumption and $\eta>0$ is the intra-temporal elasticity of substitution between domestic and foreign goods.

Given the specification for the preferences, the minimization of expenditures for given level of $C_{t}$ implies, as in Walsh (2003), the following aggregate domestic consumer price index (CPI):

$$
P_{t}=\left[(1-\alpha)\left(P_{t}^{H}\right)^{1-\eta}+\alpha\left(P_{t}^{F}\right)^{1-\eta}\right]^{\frac{1}{1-\eta}},
$$


where $P_{t}^{H}$ and $P_{t}^{F}$ are prices of domestic and foreign Dixit-Stiglitz composite goods used to produce the final composite good.

In aggregate, the household maximizes lifetime utility according to the following budget constraint:

$$
P_{t} C_{t}+E_{t}\left[Q_{t, t+1} D_{t+1}\right] \leq D_{t}+W_{t} N_{t}+T_{t}
$$

where $W_{t}$ is the nominal wage; $D_{t+1}$ is the nominal pay-off in the period $t+1$ from the portfolio held at the end of the period $t ; Q_{t, t+1}$ is the stochastic discount factor; $W_{t}$ is the nominal wage, and $T_{t}$ are transfers that include taxes and profits collected from domestic firms and importers.

Given the Dixit-Stiglitz aggregation, households optimally (cost minimization) allocate their aggregate expenditures for a foreign and domestic good according to the following demand functions:

$$
\begin{aligned}
C_{t}^{H} & =(1-\alpha)\left(\frac{P_{t}^{H}}{P_{t}}\right)^{-\eta} C_{t} \\
C_{t}^{F} & =\alpha\left(\frac{P_{t}^{F}}{P_{t}}\right)^{-\eta} C_{t} .
\end{aligned}
$$

The intra-temporal optimality condition for labor-leisure choice and the inter-temporal condition that follows from the first order conditions of the household's optimization problem can be stated as

$$
\begin{array}{ll}
C_{t}: & \lambda_{t}=e^{g_{t}}\left(C_{t}-h C_{t-1}\right)^{-\sigma} \\
N_{t}: & \lambda_{t} \frac{W_{t}}{P_{t}}=G_{t} N_{t}^{\varphi} \\
D_{t}: & \lambda_{t} E_{t}\left[Q_{t, t+1}\right]=\beta E_{t}\left[\lambda_{t+1} \frac{P_{t}}{P_{t+1}}\right],
\end{array}
$$

where $\lambda_{t}$ is the Lagrange multiplier associated with a budget constraint. To derive equation (8), we assume that households have access to a complete set of internationally traded contingent claims. In the asset pricing equation $(8), E_{t}\left[Q_{t, t+1}\right]$ is the 
stochastic discount factor of the nominal pay-off of the household's portfolio oneperiod ahead. From the definition $E_{t}\left[Q_{t, t+1}\right]=\left(1+i_{t}\right)^{-1}=R_{t}^{-1}$, it follows that $R_{t}$ is the gross interest rate on that portfolio, and $i_{t}$ is nominal interest rate. Households' optimality conditions imply the Euler equation that is given by

$$
1=\beta E_{t}\left[\left(1+i_{t}\right) \frac{\lambda_{t+1}}{\lambda_{t}} \frac{P_{t}}{P_{t+1}}\right]
$$

\subsection{International arrangements}

We define the real exchange rate as the ratio of foreign prices in domestic currency to the domestic prices $\hat{q}_{t} \equiv \hat{e}_{t} \frac{P_{t}^{*}}{P_{t}}$, where $\hat{e}_{t}$ is the nominal exchange rate (in terms of the domestic currency per unit of foreign currency); $P_{t}^{*}$ is the foreign consumer price index; and $P_{t}$ is the domestic consumer price index given by equation (3). An increase in $\hat{e}_{t}$ coincides with an appreciation of the domestic currency. Since, we assume that $P_{t}^{*}=P_{t}^{F *}\left(P_{t}^{F *}\right.$ is the price of the foreign good in a foreign currency),

the deviation from the law of one price is given by $\Psi_{t}^{F}=\hat{e}_{t} \frac{P_{t}^{*}}{P_{t}^{F}}$, as in Monacelli (2005). In here, the law of one price holds when $\Psi_{t}^{F}=1$. The deviation from the law of one price represents a wedge between the foreign price of a foreign good and the price of this good when sold at the domestic market [see Lubik (2005) for details].

The foreign economy is identical in preferences, so conditions similar to the domestic optimality conditions (6) and (7) also apply. The foreign economy is considered to be large and the domestic good takes only a negligible fraction of foreign consumption. Therefore, the foreign composite consumption bundle can be simplified and only foreign produced goods are considered in the overall foreign consumption.

Further, under the assumption of complete international financial markets, arbitrage implies that the marginal utility of consumption in foreign economy is proportional to that in domestic economy. Therefore, the following condition must be satisfied:

$$
\beta E_{t}\left[\frac{\lambda_{t+1}}{\lambda_{t}} \frac{P_{t}}{P_{t+1}}\right]=E_{t}\left[Q_{t, t+1}\right]=\beta E_{t}\left[\frac{\lambda_{t+1}^{*}}{\lambda_{t}^{*}} \frac{P_{t}^{*}}{P_{t+1}^{*}} \frac{e_{t+1}}{\hat{e}_{t}}\right]
$$


Using the asset pricing equation that determines the price of one-period bonds in the domestic and foreign economy, together with the risk sharing condition (10) imply the following uncovered interest rate parity (UIP) condition:

$$
E_{t}\left[Q_{t, t+1}\left(R_{t}-R_{t}^{*}\left(\frac{\hat{e}_{t}}{\hat{e}_{t+1}}\right)\right)\right]=0
$$

The uncovered interest rate parity places a restriction on the relative movement of the domestic and foreign interest rate and on the nominal exchange rate.

Finally, the terms of trade as the relative price of imports in terms of exports are given by:

$$
S_{t}=\frac{P_{t}^{F}}{P_{t}^{H}}
$$

Note that changes in the terms of trade may reflect the changes in the competitiveness of an economy.

\section{$2.3 \quad$ Firms}

In this economy, the nominal rigidities driving the price adjustment occurs due to the monopolistic competition in the good market. Suppose there is a continuum of domestic firms indexed by $i, 0 \leq i \leq 1$. A typical firm $i$ in the home country produces a differentiated good with constant returns to scale according to the following production function:

$$
Y_{t}(i)=A_{t} N_{t}(i)
$$

where $N_{t}(i)$ is labor supplied by a household to firm $i ; A_{t}$ is a common stationary productivity process that follows $\ln \left(A_{t}\right)=a_{t}=\rho_{a} a_{t-1}+\varepsilon_{t}^{a}$, where $\varepsilon_{t}^{a} \sim N\left(0, \sigma_{a}^{2}\right)$ is an exogenous productivity shock common to all firms. According to this production function, the firm faces real marginal $\operatorname{costs} M C_{t}=\frac{W_{t}}{P_{t} A_{t}}$, where $W_{t}$ is the nominal wage. Firm's index is dropped, while in the symmetric equilibrium all choices of the firms for producing a unit of output are the same. 
In here, firms producing a domestic good are monopolistically competitive with a Calvo-style price setting with indexation to past values of the domestic inflation rate. In here, the domestic inflation rate is defined as $\pi_{t}^{H}=\ln \left(P_{t}^{H} / P_{t-1}^{H}\right)$. Further, only a fraction $\left(1-\theta^{H}\right)$ of firms are allowed to set their price $P_{t}^{H, n e w}$ optimally in the considered period. The fraction $\theta^{H}$ sets its price according to the following indexation rule:

$$
\ln \left(P_{t}^{H}(i)\right)=\ln \left(P_{t-1}^{H}(i)\right)+\delta \pi_{t-1}^{H},
$$

where $0 \leq \delta<1$ is the degree of indexation. Therefore, the aggregate price index is evolving according to the following relation:

$$
P_{t}^{H}=\left[\left(1-\theta^{H}\right)\left(P_{t}^{H, n e w}\right)^{(1-\varepsilon)}+\theta^{H}\left(P_{t-1}^{H}\left(\frac{P_{t-1}^{H}}{P_{t-2}^{H}}\right)^{\delta}\right)^{(1-\varepsilon)}\right]^{1 /(1-\varepsilon)}
$$

where $\varepsilon>1$ is the elasticity of substitution between the varieties of goods produced by domestic firms. The firm $i$, setting its price in period $t$ and following the indexation rule in subsequent periods $T, T \geq t$ faces the following demand curve in period $T:$

$$
y_{T}^{H}(i)=\left(\frac{P_{t}^{H, \text { new }}(i)}{P_{T}^{H}}\left(\frac{P_{T-1}^{H}}{P_{t-1}^{H}}\right)^{\delta}\right)^{-\varepsilon}\left(C_{T}^{H}+C_{T}^{H *}\right),
$$

where $C_{t}^{H}$ is domestic demand and $C_{t}^{H *}$ is foreign demand for the composite domestic good. While firm $i$ is maximizing its present value by maximizing the value of the stream of real profits, firm's price-setting problem in period $t$ is to solve:

$$
\max _{P_{t}^{H}(i)} E_{t} \sum_{T=t}^{\infty}\left(\theta^{H}\right)^{T-t} Q_{t, T} y_{t}^{H}(i)\left[\frac{P_{t}^{H, \text { new }}(i)}{P_{t}^{H}}\left(\frac{P_{T-1}^{H}}{P_{t-1}^{H}}\right)^{\delta}-M C_{T}\right]
$$

subject to the aforementioned demand curve. This implies the following first order condition:

$$
E_{t} \sum_{T=t}^{\infty}\left(\theta^{H}\right)^{T-t} Q_{t, T} y_{t}^{H}(i)\left[P_{t}^{H, n e w}(i)\left(\frac{P_{T-1}^{H}}{P_{t-1}^{H}}\right)^{\delta}-\frac{\varepsilon}{1-\varepsilon} P_{t}^{H} M C_{T}\right]=0
$$

where $M C_{T}$ are real marginal costs of the produced unit in the period of price 
decision.

Similarly, as in the domestic good production, the nominal rigidities in the foreign good sector are resulting from staggered price setting and monopolistic competition. Foreign good retailers import foreign goods so that the law of one price holds "at the docks" and resell there in a monopolistically competitive market. To set their prices, importers also use Calvo pricing with indexation to past inflation, which is defined as $\pi_{t}^{F}=\ln \left(P_{t}^{F} / P_{t-1}^{F}\right)$.

Again, only a fraction $\left(1-\theta^{H}\right)$ of importers are allowed to set their new price $P_{t}^{F, n e w}$ optimally in each period. The fraction $\theta^{H}$ of importers just updates its price according to the following indexation rule:

$$
\ln \left(P_{t}^{F}(i)\right)=\ln \left(P_{t-1}^{F}(i)\right)+\delta \pi_{t-1}^{F},
$$

where we assume the same degree of indexation as for domestic producers. The foreign good price index is evolving according to the following relation:

$$
P_{t}^{F}=\left[\left(1-\theta^{F}\right)\left(P_{t}^{F, n e w}\right)^{(1-\varepsilon)}+\theta^{F}\left(P_{t-1}^{F}\left(\frac{P_{t-1}^{F}}{P_{t-2}^{F}}\right)^{\delta}\right)^{(1-\varepsilon)}\right]^{1 /(1-\varepsilon)}
$$

Importer $i$ that is setting its price in period $t$ faces the following demand curve in period $T, T \geq t$ :

$$
y_{T}^{F}(i)=\left(\frac{P_{t}^{F, \text { new }}(i)}{P_{T}^{F}}\left(\frac{P_{T-1}^{F}}{P_{t-1}^{F}}\right)^{\delta}\right)^{-\varepsilon} C_{T}^{F},
$$

as for the domestic good, in here $\varepsilon>1$ is substitution between the varieties of foreign goods. Therefore, firm's price-setting problem in period $t$ is to maximize

$$
E_{t} \sum_{T=t}^{\infty}\left(\theta^{F}\right)^{T-t} Q_{t, T} y_{t}^{F}(i)\left[\frac{P_{t}^{F, n e w}(i)}{P_{t}^{F}}\left(\frac{P_{T-1}^{F}}{P_{t-1}^{F}}\right)^{\delta}-\hat{e}_{T} P_{t}^{F} M C_{T}\right]
$$

subject to the aforementioned demand equation (14). This implies the following first 
order condition

$$
E_{t} \sum_{T=t}^{\infty}\left(\theta^{F}\right)^{T-t} Q_{t, T} y_{t}^{F}(i)\left[P_{t}^{F, n e w}(i)\left(\frac{P_{T-1}^{F}}{P_{t-1}^{F}}\right)^{\delta}-\frac{\varepsilon}{1-\varepsilon} \hat{e}_{T} P_{t}^{F} M C_{T}\right]=0
$$

and the optimal price is solution to this equation. The presence of monopolistic competition results in deviations from the law of one price in the short run, while a complete pass-through is reached in the long-run as presented in Monacelli (2005).

\subsection{Equilibrium}

Equilibrium requires that all markets clear. The good market clearing condition in the domestic economy is given by following equation:

$$
Y_{t}^{H}=C_{t}^{H}+C_{t}^{H *}
$$

Under the assumption of a large foreign economy, the market clearing in the foreign economy gives $Y_{t}^{*}=C_{t}^{*}$. Households are assumed to have an identical initial wealth so they make identical consumption and portfolio decisions. Because the following analysis considers a symmetric equilibrium, domestic producers, importers, and foreign firms also behave identically. Therefore, we can work with the representative household, representative firm, and the single good in each sector. So the representative domestic producers set in period $t$ common prices $P_{T}^{H}$. Further, importers also set a common price $P_{t}^{F}$, so do the foreign producers when setting $P_{t}^{*}$. Finally, as in Gali and Monacelli (2002) and (Justiniano and Preston 2004), we assume that the government off-sets distortions originating from monopolistic competition in the goods markets by subsidy/transfer that is financed through a lump-sum tax $T_{t}$ on household. 


\subsection{A Log-linearized model}

To analyze the behavior of the model, an approximation around the non-stochastic steady state of the presented model is obtained as in Justiniano and Preston (2004). For any variable, we denote by lowercase letters the log-deviation from the steady state of their uppercase counterparts that arise in the frictionless equilibrium. The non-stochastic steady state is characterized by setting all shocks to zero for all periods.

As in Justiniano and Preston (2004), we assume a non-inflationary steady state

$\frac{P_{t}}{P_{t-1}}=\frac{P_{t}^{H}}{P_{t-1}^{H}}=\frac{P_{t}^{F}}{P_{t-1}^{F}}=1$, and for the steady state, the interest rate follows $1+i_{t}=\frac{1}{\beta}$.

Linearizing the domestic goods market clearing condition (15) together with a linearized version of the demand functions (5) implies

$$
(1-\alpha) c_{t}=y_{t}-\alpha \eta(2-\alpha) s_{t}-\alpha \eta \psi_{t}^{F}-\alpha y_{t}^{*}
$$

where $\psi_{t}^{F}=\left(e_{t}+p_{t}^{*}\right)-p_{t}^{F}$ is a log-linear approximation of the law of one price gap, and $s_{t}=p_{t}^{F}-p_{t}^{H}$ is a log-linear approximation of the terms of trade given by equation (12). Time differentiating of the terms of trade definition implies

$$
\Delta s_{t}=\pi_{t}^{F}-\pi_{t}^{H}
$$

Using the log-linearized equations of the law of one price gap and terms of the trade, the following link between the terms of trade and the real exchange rate can be derived:

$$
q_{t}=\psi_{t}^{F}+(1-\alpha) s_{t}
$$

Log-linear approximation to the optimality conditions of domestic firms for price setting, the law of motion for the domestic producers price, and the domestic price 
index given by equation (13) imply the following hybrid Philips curve:

$$
\pi_{t}^{H}-\delta \pi_{t-1}^{H}=\frac{1-\theta^{H}}{\theta^{H}}\left(1-\theta^{H} \beta\right) m c_{t}+\beta E_{t}\left[\left(\pi_{t+1}^{H}-\delta \pi_{t}^{H}\right)\right]
$$

where

$$
m c_{t}=\varphi y_{t}-(1+\varphi) a_{t}+\alpha s_{t}+\sigma(1-h)^{-1}\left(c_{t}-h c_{t-1}\right)
$$

denotes the log-linear form of the real marginal cost function of the representative firm that originates from the log-linearization of the aggregate production function and the household's optimality condition for labor choice.

Similarly, the optimality condition for the pricing problem of retailers results in the following Philips curve

$$
\pi_{t}^{F}-\delta \pi_{t-1}^{F}=\frac{1-\theta^{F}}{\theta^{F}}\left(1-\theta^{F} \beta\right) \psi_{t}^{F}+\beta E_{t}\left[\left(\pi_{t+1}^{F}-\delta \pi_{t}^{F}\right)\right] .
$$

Following the arguments of Justiniano and Preston (2004) and the derivation presented by Gali and Monacelli (2002), the complete markets assumption together with condition (10) imply for the log-linear approximation of the Euler equation (9) the following relation

$$
c_{t}-h c_{t-1}=y_{t}^{*}-h y_{t-1}^{*}+\sigma^{-1}(1-h)\left[\psi_{t}^{F}+(1-\alpha) s_{t}\right]+\sigma^{-1}(1-h) g_{t} .
$$

The log-linear approximation of the uncovered interest rate parity equation (11) gives $i_{t}-i_{t}^{*}=E_{t} \Delta e_{t+1}$. However, the interest rate parity can be distorted by a risk premium shock such as a time varying risk premium, that can not be explained endogenously through imperfect pass-through. Therefore, as in Kollmann (2002), to capture deviations from uncovered interest rate parity in the log-linearized form a risk premium shock $\epsilon_{t}$ is added. In here $\epsilon_{t}$ is $\operatorname{AR}(1)$ process $\epsilon_{t}=\rho_{s} \epsilon_{t-1}+\varepsilon_{t}^{s}$, where $\varepsilon_{t}^{s} \sim N\left(0, \sigma_{s}^{2}\right)$. 
Plugging the log-linear form of the definition of the real exchange rate

$$
\Delta e_{t}=\Delta q_{t}+\pi_{t}-\pi_{t}^{*}
$$

in the approximation of equation (11), it follows

$$
\left(i_{t}-E_{t} \pi_{t+1}\right)-\left(i_{t}^{*}-E_{t} \pi_{t+1}^{*}\right)=E_{t} \Delta q_{t+1}+\epsilon_{t}
$$

The risk premium shock $\epsilon_{t}$ is constant in steady state and equation (24) collapses to a standard uncovered interest rate parity equation for the nominal exchange rate in steady state.

Finally, the approximations of the CPI equation (3) and the change in terms of trade (17) give the following relation:

$$
\pi_{t}=\pi_{t}^{H}+\alpha \Delta s_{t}
$$

Since the goods produced in the home economy represent only a small fraction of the foreign economy consumption, we considered a large foreign economy as closed and exogenous to the domestic economy. This gives us some flexibility in specifying the behavior of foreign variables. Therefore, we assume that the paths of foreign variables $\pi_{t}^{*}, y_{t}^{*}$, and $i_{t}^{*}$ are determined by the following VAR process:

$$
\begin{aligned}
\pi_{t}^{*} & =\omega_{\pi}^{\pi} \pi_{t-1}^{*}+\omega_{y}^{\pi} y_{t-1}^{*}+\omega_{i}^{\pi} i_{t-1}^{*}+\varepsilon_{t}^{\pi}, \\
y_{t}^{*} & =\omega_{\pi}^{y} \pi_{t-1}^{*}+\omega_{y}^{y} y_{t-1}^{*}+\omega_{i}^{y} i_{t-1}^{*}+\varepsilon_{t}^{y}, \\
i_{t}^{*} & =\omega_{\pi}^{i} \pi_{t-1}^{*}+\omega_{y}^{i} y_{t-1}^{*}+\omega_{i}^{i} i_{t-1}^{*}+\varepsilon_{t}^{i},
\end{aligned}
$$

where $\varepsilon_{t}^{\pi}, \varepsilon_{t}^{y}$, and $\varepsilon_{t}^{i} ; \varepsilon_{t}^{y} \sim N\left(0, \sigma_{y}^{2}\right), \varepsilon_{t}^{\pi} \sim N\left(0, \sigma_{\pi}^{2}\right)$, and $\varepsilon_{t}^{i} \sim N\left(0, \sigma_{i}^{2}\right)$, represent the independent structural shocks that drive the foreign economy. 


\subsection{Monetary regime}

The description of the underlying model that consists of equations (16)-(28) and the definitions of the $\mathrm{AR}(1)$ processes for technology, preference, and risk premium shocks, is closed by describing the behavior of the domestic monetary authority. First, we describe the forms of the monetary regimes for the pre-transition (before the announcement of the regime switch) and final (after the new regime is adopted) periods. The regimes for the pre-transition and post-transition periods represent standard monetary regimes. Further, our approach to modeling the transition period is presented in the following sub-section, where the model extension and the regime for the transition period are described in detail.

First, we assume that the monetary regime is conducted according to an inflation forecast based Taylor rule in the following form:

$$
i_{t}=\rho i_{t-1}+\rho_{\pi} \pi_{t+1}+\rho_{y} y_{t}+\rho_{e} \Delta e_{t}+\varepsilon_{t}^{m},
$$

where $\rho \mathrm{s}\left(\rho_{\pi}>1, \rho_{y}>0\right.$ and $\left.\rho_{e} \geq 0\right)$ are weights describing the responses of the domestic monetary authority, and $\varepsilon_{t}^{m}, \varepsilon_{t}^{m} \sim N\left(0, \sigma_{m}^{2}\right)$ is the shock capturing errors arising from the description of the monetary policy. In here, we deviate from Justiniano and Preston (2004). As discussed by Carlstrom and Fuerst (2000), we assume that monetary authority acts according to expected inflation $\left(\pi_{t+1}=\right.$ $\left.E_{t}\left(\pi_{t+1}\right)\right)$ rather than using the actual level of inflation. To keep our analysis simple, we assume that the monetary authority is forward looking for only one period ahead.

First, setting different values for the Taylor rule parameters $\rho_{\pi}, \rho_{y}$ and $\rho_{e}$ allows us to model a wide range of monetary regimes types, e.g. inflation targeting or exchange rate targeting. Regimes given by equation (29) are used to describe the behavior of the monetary authority with an independent monetary policy (the pretransition period in our experiment), in the case where the domestic authority is free to set weights of its rule.

Second, as mentioned in the introductory section, we focus on analyzing the 
behavior of a small open economy that announces in period $k$ the adoption of a specific monetary regime that will become effective in the period $T, T>k$. In our analysis, the only objective of the announced regime is to off-set changes in the nominal exchange rate, so we set $\rho=\rho_{\pi}=\rho_{y}=0$ in the general form (29). Therefore, the post-transition regime takes the following form

$$
i_{t}=\widehat{\rho^{e}} \Delta e_{t}
$$

where $t \geq T$ and $\hat{\rho}_{e}>1$ are the measures for off-setting of the change in the nominal exchange rate. To keep the level of exchange rate volatility in the post-transition regime close to the volatility in the pre-transition regime (for $t<k$ ) focusing on the exchange rate, we set $\widehat{\rho}_{e}=1.25$. Further, we assume that there will be no future shocks (for $t \geq T$ ) to risk premium, so $\epsilon_{t}$ described by equation (24) will become $\epsilon_{t}=\rho_{s} \epsilon_{t-1}$ in the model of the post-transition (final) regime.

\subsection{The transition period model}

The focus of this paper is to analyze macroeconomic stability over the transition period from a pre-transition regime towards the aforementioned post-transition regime. Therefore, the model of the transition period employs a composite rule for the monetary regime. To specify the used composite rule, the monetary authority announces a rule that will be followed over the transition period and the time of the regime switch. We assume that the monetary regime over the transition period is the same as the pre-transition regime. This means that the monetary authority keeps the pre-transition regime also over the transition period.

Therefore, the composite monetary policy rule for the transition period includes rules (29) and (30). These rules are combined with the help of a regime indicator, so the transition period rule takes the following form:

$$
i_{t}=\operatorname{regime}_{t}\left(\rho i_{t-1}+\rho_{\pi} \pi_{t+1}+\rho_{y} y_{t}+\rho_{e} \Delta e_{t}+\varepsilon_{t}^{m}\right)+\left(1-\text { regime }_{t}\right) \widehat{\rho}^{e} \Delta e_{t},(31)
$$


where the

$$
\text { regime }_{t}= \begin{cases}1, & \text { if } t<T ; \\ 0, & \text { if } t \geq T\end{cases}
$$

and $T$ is the time of the regime switch.

Our approach to modeling the transition period consists of the creation of an information buffer by an extension of state space of the underlying model. The information buffer, capable of storing information for $N$ periods, takes the following form:

$$
\begin{aligned}
\text { regime }_{t} & =i n f_{t, 1} \\
i n f_{t, 1} & =\rho_{i n f} i n f_{t, 2}+\nu_{t, 1} \\
i n f_{t, 2} & =\rho_{i n f} i n f_{t, 3}+\nu_{t, 2} \\
& \vdots \\
i n f_{t, N-1} & =\rho_{i n f} i n f_{t, N}+\nu_{t, N-1} \\
i n f_{t, N} & =\nu_{t, N},
\end{aligned}
$$

where $i n f_{t, i}, i \in 1, \ldots, N$ are new endogenous variables, $\nu_{t, i}, i \in 1, \ldots, N$ are information shocks, and $0<\rho_{\text {inf }}<1$. Under the assumption that the $\nu_{t, i} \sim N\left(0, \gamma^{2}\right), \forall i$ and $\gamma^{2} \in \Re^{+}$. Using this assumption, we can model the uncertainty about keeping the commitment of the regime switch announced by the monetary authority. The higher the uncertainty about keeping commitments, the higher the value of information shock variance $\gamma^{2}$ should be used. However in this work, we focus on the perfectly credible announcements. Therefore, we can think about $\nu_{t, i} \mathrm{~s}$ as random variables with zero variance and zero mean.

Let us consider that in the time period $k$ a regime change in $T$ periods is announced, where $0<T \leq N$. This announcement is equivalent to the realization of information shocks $\nu_{k, i}, i \in\{1, \ldots, N\}$ and are realized according to the following 
scheme:

$$
\nu_{k, i}= \begin{cases}\rho^{1-i}, & i \leq T \\ 0, & i>T\end{cases}
$$

and $\nu_{l, i}=0, \forall i$ and in the all subsequent periods $l, l>k$. This realization of information shocks means that there is a one-time announcement of a regime switch, and there are no further changes to time of the regime switch. In the following analysis, we will recognize the period of announcement as the initial period, while it is the initial period of transition.

Finally, the model of the transition period consists of equations (16)-(28), the information buffer given by equations (32), and the definitions of the AR(1) processes for technology and preference shocks. As mentioned in the previous section, we assume that the risk premium shock disappears after the regime switch, so the AR(1) process for the risk premium shock $\epsilon_{t}$ in equation (24) in the model of transition will become $\epsilon_{t}=\rho_{s} \epsilon_{t-1}+$ regime $_{t} \varepsilon_{t}^{s}$, where $\varepsilon_{t}^{s} \sim N\left(0, \sigma_{s}^{2}\right)$.

When solving the model and since the linear approximation is used, there are no steady-state effects arising from the model extension. So, the steady state of the model with an information buffer coincides with the steady state model with rule (30). The construction of the regime indicator implies non-linearities in the form of the monetary regime rule. Therefore, to solve and simulate the transition regime, we use Dynare $++{ }^{2}$ Employing Dynare ++ , we are able to use second-order approximations in our experiments. The second order approximation is essential because of the quadratic nature of the monetary regime rule in the model of the transition regime.

The solution of the transition period model given by equations (16)-(28), and

\footnotetext{
${ }^{2}$ Dynare ++ , developed by Kameník (2007), is a standalone $\mathrm{C}++$ version of Dynare. Dynare is the pre-processor and collection of Matlab routines introduced by Juillard (1996), Collard and Juillard (2001b) and Collard and Juillard (2001a) is used
} 
equations (32) takes the following general form:

$$
x_{t+1}=F\left(x_{t}, \varepsilon_{t}, \nu_{t}\right) \text {, }
$$

where $x_{t}$ is the vector of the model variables, $\varepsilon_{t}$ is the vector of foreign and domestic structural shocks, $\nu_{t}=\left\{\nu_{t, 1}, \ldots, \nu_{t, N}\right\}$ is the vector of information shocks, and $F($. is the second-order polynomial. However, due to the independence of information and structural shocks after the evaluation of information shocks (an announcement of the transition period length), the system will be linear. Therefore, the transition period model with a given length of the transition period takes the following form:

$$
x_{t+1}=A_{t} x_{t}+B \varepsilon_{t},
$$

where matrices $A_{t}, t=1, \ldots, N$ and matrix $B$ depend on the structural parameters of the model and the transition period length. However for $t_{1}, t_{2}>T$, we have $A_{t_{1}}=$ $A_{t_{2}}$ because $\nu_{t}$ for $t>T$ is a vector of zeros. The state-space solution conditional on transition period length (33) is used to simulate the model and compute the covariance matrices $\Sigma_{t}$. We compute the covariance matrix $\Sigma_{t}$ recursively using the following formula:

$$
\Sigma_{t+1}=A_{t} \Sigma_{t} A_{t}^{T}+B \varepsilon_{t},
$$

where $\Sigma_{0}$ is the covariance matrix from the model of the independent monetary policy. Further, for the model of post-transition for $t>T$, we use the following formula

$$
\Sigma_{t+1}=A^{f} \Sigma_{t} A^{f^{T}}+B^{f} \varepsilon_{t},
$$

where matrices $A^{f}$ and $B^{f}$ are taken from the solution of the model with the posttransition monetary policy regime. 


\section{Estimation methodology}

In recent literature, Bayesian methods are considered as an attractive tool for the estimation of a model's parameters, especially in open economy modeling. The most recent examples include Smets and Wouters (2003), which estimates the Eurozone model; Lubik and Schorfheide (2003) and Lubik and Schorfheide (2005), which analyze the behavior of the monetary authority and the identification problems; and Ireland (2004).

We prefer Bayesian methods while according to the aforementioned studies, the use of priors makes the estimation results more stable. Due to the short span of the Czech data sample, we incorporate information from previous studies in the form of priors on parameter estimates. This allows us to use informative rather than flat priors.

Model $M$ and its associated parameters $\Theta$ can be estimated using the method outlined by An and Schorfheide (2007). In the Bayesian context, given a prior $p(\Theta)$ and a sample of data $Y$, the posterior density of the model parameters $\Theta$ is evaluated, and it is proportional to the likelihood of the data multiplied by the prior $p(\Theta)$ :

$$
p(\Theta \mid Y, M) \propto L(\Theta \mid Y, M) p(\Theta),
$$

the goal of the Bayesian estimation is to estimate the posterior distribution and to find such parameter estimates that given the model likelihood $L(\Theta \mid Y, M)$, are maximized.

The Bayesian estimation procedure consists of the following three steps. In the first step, the model is extended for a measurement block that links model variables to data. The extended model is solved. In the second step, the fact that the solution of the model is in the form of a state space model is exploited. This allows us to compute the likelihood function of the underlying model by use of the Kálmán filter, the observed data, and priors. The objective is to maximize the value of likelihood as the function of the model parameters. The second step results in the maximum- 
likelihood estimates of the model parameters. The objective of these estimation steps is to get parameter values for our model.

In the third step, the likelihood function conditional on a parameters estimate is combined with the prior distribution of parameters to obtain the posterior density function. In here, the modes of the posterior distributions are identified by the maximum-likelihood estimates from the second step. We search for the posterior distributions using Monte Carlo Markov chain (MCMC) method. In our estimation of posterior distribution, an implementation of the Metropolis-Hastings (MH) algorithm is used as an MCMC algorithm. The objective of the posterior distributions computation is to evaluate the sensitivity of results to our choice of priors and optimization algorithm settings.

\subsection{Estimation}

We estimate the parameters of the model using data on the Czech Republic. Our data sample covers the period of an inflation targeting regime from its introduction in 1998 until the third quarter of 2007. Over this period the Czech National Bank committed to follow an inflation targeting monetary policy. The policy change that occurred over the considered period was switched from core inflation targeting to CPI targeting. However, we do not consider this policy change as a crucial problem for our estimation. Due to the fact that we use the de-trended series, we also can abstract from the effects of a decreasing inflation target. The detailed description of data and transformations used are summarized in the Appendix A.1.

The domestic block of the underlying model is estimated using the de-trended data on output growth, inflation, the nominal interest rate, terms of trade, and the real exchange rate. The foreign block is described by the de-trended series of effective output, inflation, and the nominal interest rate. The effective series are constructed from the series of the main trade partners of the Czech Republic. These series are weighted using the export based weights of trade partners.

Model variables are expressed in percentage deviations from a steady state. Data 
series are related to model variables via a block of measurement equations. In these equations, we connect the model variables with the observed data using the measurement error. The block of measurement equations and measurement errors characteristics are summarized in the Appendix A.2.

Our choice of parameter priors is mostly derived from previous studies [e.g. Lubik and Schorfheide (2003) and Justiniano and Preston (2004)] and is guided by several considerations. The choice of prior distributions reflects the restrictions on the parameters such as the non-negativity deviations or interval constraints. Therefore, for parameters constrained to $<0,1>$ interval, the beta distribution is used. Prior distributions for standard deviations of shocks have been set to inverse gamma. Similarly, for parameters taking positive values, the gamma distribution is used. Standard deviation of priors also reflect our beliefs and confidence in the value of parameters. There are only few studies estimating DSGE models of the Czech Republic. Therefore, we decided to use rather loose priors than tighter ones. Tables (5) and (6) provide an overview of our choice of priors and we assume (strict prior) $\beta=0.99$, which implies an annual interest rate of about $4 \%$ in a steady state.

For construction of the joint probabilistic distribution, we also assume that the priors are independent of each other. This simplifies the use of the MCMC algorithm. We use the Dynare toolbox to estimate the presented model. Given the data and priors, we generate 300,000 draws for each of the 5 Markov chains using the MH algorithm. While the acceptance rates between $20 \%$ and $40 \%$ are considered as reasonable for distribution sampling, we set the scaling parameter for jumping distribution in $\mathrm{MH}$ so that the average acceptance rate is 0.32 .

\subsection{Estimation results}

Estimation results are summarized in Tables (5) and (6) in the Appendix A.3. The analysis of the posterior distributions together with posterior density for values around the computed mode for each estimated parameter did not indicate the presence of computational problems. The reported results show that there is no simple 
relation between priors motivated by previous studies and estimates supported by data.

The parameter $\alpha$ is estimated to be 0.38 , and this value is close to the estimate by Natalucci and Ravenna (2003). Moreover, we believe that this value reflects the characteristics of the Czech Republic and evidence from openness measures based on import and export to domestic product ratios. We also consider this value consistent with the value 1.01 of foreign-home good substitution $\eta$ because it indicates that for households, the foreign and domestic goods are Cobb-Douglas substitutes.

The value 0.11 of inverse elasticity of inter-temporal substitution $\sigma$ implies low relative risk aversion and high elasticity of inter-temporal substitution. The high value of elasticity indicates that consumption responds strongly even to small changes in the interest rate. The high value of habit persistence (0.72) indicates that households are also concerned about their level of consumption. When a change in consumption occurs, households try to maintain the new level of consumption. Also, the high value of inverse elasticity of labor substitution, $\phi=3.36$, implies significant non-elasticity of the labor supply. We believe that this reflects the low volatility of hours worked as statistics show for the Czech labor market, especially at the beginning of the considered period.

According to estimation results, the interest rate smoothing $\rho_{i}$ takes just a slightly higher value than our prior. The reaction to inflation and the output gap deviation are taking values 1.48 and 0.43 , respectively. These values of $\rho_{\pi}$ and $\rho_{y}$ reveal that keeping future inflation at the level of inflation target is preferred more than 3.4 times than closing the output gap. Moreover, the low value of reaction to the deviation of the nominal exchange rate $\rho_{e}$ is consistent with the inflation targeting focus declared by the Czech National Bank.

Our priors for the price stickiness parameters $\theta^{\prime}$ s are chosen based on Lubik and Schorfheide (2005), and they reflect the evidence on US prices. The prior value of price indexation is set to 0.5 , while studies exist where the value of indexation is set to unity. Our estimation results show that there is a low fraction of domestic 
firms (estimate of $\theta_{H}$ takes the value 0.13 ) that optimize their prices every quarter. This is consistent with estimates using the European data presented by Smets and Wouters (2003). On the contrary, importers optimize their prices more often so the average contract length is approximately 3 months $[1 /(1-0.68)]$. The high value of inflation means that the good price is updated for a large fraction of the price level change. Therefore, the estimated value of 0.63 for the inflation indexation $\delta$, that is almost twice as high as the values reported by Justiniano and Preston (2004), supports our estimates of the low frequency of price optimization.

We assume a high persistency of technological, risk premium and taste shocks, so the priors are set to 0.85 . However, estimates show that the most persistent shock is the preference shock with a value of 0.95 for $\rho_{g}$. We also find that the estimated value of 0.81 for persistency of a technological shock is higher than the value $(0.7)$ used by Justiniano and Preston (2004).

For the foreign block, we assume the autocorrelation of foreign shocks to be 0.7 [used by Natalucci and Ravenna (2002)], while we find the values of Justiniano and Preston (2004) quite low. However, our estimation results show a low persistency in the foreign block for inflation and the nominal interest rate series. Only the output series reveal a higher persistency than assumed.

Priors and estimates of the standard deviation of structural shocks are summarized in Table (6). These results show that the most volatile is the preference shock $\varepsilon_{t}^{g}$. However, this does not mean that the preference shock is the main driving force of the variables of our interest. Using the variance decomposition, we found out that the preference shock generates only $9 \%$ of inflation, $5 \%$ of output growth, and $7 \%$ of the nominal interest rate variance. Due to the high value of the openness, we found that the risk premium is responsible for $42 \%$ of CPI inflation variance. However, for the estimated coefficients variance, decomposition shows that the foreign shocks do not generate significant shocks for the domestic economy. Each shock to foreign inflation, output, and the interest rate is responsible for approximately $3 \%$ of the domestic inflation variance. 


\begin{tabular}{l|rr|rr}
\hline \multirow{2}{*}{ Variable } & \multicolumn{2}{|c|}{ Data } & \multicolumn{2}{c}{ Model } \\
\hline \hline Output growth & Std. dev. & Corr. & Std. dev. & Corr. \\
Nominal interest rate & 1.05 & 1.00 & 3.04 & 1.00 \\
CPI inflation & 1.38 & -0.53 & 1.84 & -0.26 \\
Change in nominal ex. rate & 3.14 & -0.12 & 4.02 & -0.15 \\
Real ex. rate & 8.37 & 0.17 & 8.54 & 0.02 \\
Foreign output gap & 3.48 & 0.17 & 6.79 & -0.03 \\
Foreign inflation & 0.81 & 0.02 & 0.67 & 0.00 \\
Foreign nom. int. rate & 0.66 & 0.21 & 0.76 & -0.01 \\
\hline
\end{tabular}

Table 1: Moments summary

To evaluate the empirical properties of the generic model, Table (1) compares moments of time series used for the estimation with moments of variables of the estimated model. Using this comparison, we conclude that our model over-estimates the volatility of output and real exchange rate.

Finally, to evaluate the amount of information included in the observed series, we use a comparison of priors and posteriors distributions. This comparison helps to gain insight into the extent to which the data provide information about the estimated parameters. According to the figures presented in Table (7), we conclude that the observed data contain a portion of information that lead to an update of our priors.

\section{Impulse response analysis}

In this section, we compare the results of our simulations of the impulse responses for the estimated model and for the model of the transition period [model with the monetary policy rule (31)]. The goal of this comparison is to point at differences that are induced by adding information on a monetary regime switch in the model that allows for it. Figures 1-7 present impulse response functions of the following four models: estimated model (solid red line); model of regime switch in 4 (dash-doted magenta line); 8 (dashed blue line); and 40 (dotted black line) periods.

Figure (1) depicts responses to the technology shock $\varepsilon_{t}^{a}$. As it is expected for 
the case of a supply shock, output increases and inflation decreases. Via uncovered interest rate parity relation, the decrease in the domestic inflation is also accompanied with a currency appreciation (since the inflation and interest rate of a foreign economy does not react to domestic shocks). The monetary authority reacts by decreasing interest rates. Due to the appreciation and the fact that importers do not update their prices immediately for a lower input cost, the law-of-one-price (LOOP) gap reaches negative values, indicating importers' profits. These profits are returned to households and used to finance a subsequent increase in consumption. The presence of habit formation also supports the observed hump-shaped consumption profile because households gradually adjust their consumption profile. However, an update of imported good prices, with slowing appreciation and real depreciation, restrain the rise in demand for foreign goods. As inflation in the imported good sector rises the steady state is established. Due to the imported price rigidity and appreciation in the case of a late regime switch (in 8 and 40 periods), exporters face losses. For the case of a late regime switch, we observe very expansive monetary policy that is the result of a slower return of currency appreciation to its steady state.

The main difference in responses between the model of regime switch and the model of an independent monetary policy is in the extent of deviation from the steady state. Due to the expected regime switch, the monetary authority reacts with a more expansionary policy, to establish steady a state of change in the nominal exchange rate. As expected, the response of the monetary policy is followed by a larger consumption increase than in the model of independent policy.

Figure (2) presents a response to the domestic taste shock $\varepsilon_{t}^{g}$. This shock initiates an increase in domestic inflation and in the output as expected in the case of a demand shock. In reaction to a subsequent inflation increase, the domestic currency appreciates in the initial period. Because of the initial currency appreciation, importers decrease the prices of their goods and imported inflation decreases. Foreign goods become cheaper and the expected switch to foreign goods translates into higher foreign good prices. The international price of a foreign good does not change 
because the foreign economy is large and does not react to the domestic demand. In the case of a no-regime switch model, the import price decrease has a larger extent than in the case of a regime change, and this makes households increase their demand for foreign goods. This results from the reaction of the monetary authority that has to prevent the extensive appreciation and initially runs an expansionary policy in the case of the regime switch. Due to output rigidities, the increase in output follows with a lag. In response to the inflation and output increase, the domestic monetary authority increases the interest rate. Due to the long duration of contracts in the import sector, the LOOP gap is negative (importers enjoy profits), especially in a case of the model without the possibility of a regime switch.

Figure (3) presents responses to the risk premium shock $\varepsilon_{t}^{s}$. In the case of an announced change of regime, this leads to initial depreciation and an immediate increase in the interest rate to prevent further depreciation and an inflation rise. However, strong reaction leads to an appreciation and an immediate drop in the interest rate to prevent from deflation. In the case of a model with regime switch, this behavior originates from the design of the monetary policy rule given by equations (30) and (31). The extent of the interest rate reaction is the main difference between analyzed models. In the model with the regime switch, the monetary authority strongly increases the interest rate in order to fully off-set the change in the nominal exchange rate. A contractionary response is consistent with a weak output and consumption increase and with a positive deviation of the LOOP gap. However, due to the extent of the depreciation and the indexation of import prices, a significant increase in imported inflation is observed.

In the case of a monetary policy shock $\varepsilon_{t}^{m}$ [Figure (4)], the shape of the responses does not differ much between models because of the low persistency of this shock. A positive monetary policy shock is equivalent to a contractionary policy. Therefore, output decreases together with consumption as inter-temporal substitution motivate households to postpone consumption. This results in a decrease of import inflation. Due to the interest rate differential, domestic currency appreciates and imports 
become cheaper. The terms of trade increase initially signal a future increase in competitiveness of the domestic economy. Over time, the interest rate is decreases to suppress the effect of a contractionary monetary policy, and with contribution of interest rate smoothing a short period of currency depreciation is observed. Increase in competitiveness and decreasing interest rate policy help to establish a steady state for output. However, due to high rigidity in foreign goods pricing, it takes much longer for imported inflation to reach a steady state than for domestic inflation.

Responses to a foreign inflation shock $\varepsilon_{t}^{\pi}$ are presented in Figure (5). An increase in the foreign inflation rate leads to an immediate appreciation of the domestic currency (implied by UIP). An increase in imported inflation leads to an increase of domestic inflation. In the model without a regime switch, the domestic inflation increase leads to an increase in expected inflation, so the monetary authority reacts with a contractionary policy. Also, an increase in the domestic inflation results in an increase of marginal costs. Together with initial worsening of the terms of trade, this suppresses domestic output and an initially negative response of consumption is expected.

However, this form of response is not observed in the model with a regime switch. In the model of a regime switch, a rise in imported inflation via offsetting the change in the nominal exchange rate is foreseen, so in the initial periods contractionary policy is conducted. Meanwhile, as a reaction to an increase in foreign inflation, a foreign interest rate is increased. This reverts appreciation to depreciation and leads to an increase in CPI inflation in both models. The elimination of the foreign-domestic inflation differential and a subsequent domestic currency depreciation follows due to the fact that foreign inflation persistency is much lower than the persistency of foreign interest rates. We see the high rigidity of imported goods pricing as the main reason for the lagged increase in imported good inflation (hump-shape).

Figure (6) depicts responses to the foreign positive output shock $\varepsilon_{t}^{y}$. An increase in the foreign output leads to an increase in demand for domestic goods and domestic inflation, so domestic output rises in response to this shock. An inflation increase 
leads to currency depreciation in the case of the model without a regime switch. Because of high rigidity in foreign demand and the gradual adjustment of a household's consumption profile, we observe a hump-shaped decrease in consumption as response to foreign demand.

For the foreign output shock, the main differences in responses occur in the initial period. In the model with the announced regime switch, the nominal exchange rate appreciates and inflation decreases as the increase in foreign inflation is expected. This make foreign goods cheaper relative to domestic goods. Therefore, households are also able to increase their consumption of domestic goods and the increase in demand drives increase in output. The growth of output leads to an increase in the marginal cost of production and in a rise of inflation. Therefore, the domestic monetary authority has to increase nominal interest rates in the case of an early regime switch. In contrast, for the late change of regime, growth of output and consumption are supported with an expansionary policy. In this case, the system returns to a steady state before the regime switch is effective, and therefore, there is no reaction from the monetary authority needed to eliminate the change in the nominal exchange rate. Notice that for models with a late change of regime, inflation, consumption, and output are more volatile than in the case of no regime switch.

Finally, Figure (7) depicts responses to the positive shock to foreign interest rate $\varepsilon_{t}^{i}$. The UIP implies an initial depreciation of domestic currency because of the negative interest rate differential for both models. However, the extent of the reaction differs significantly. Further, due to the depreciation of the domestic currency, the real exchange rate and TOT depreciate. TOT depreciation implies a drop in competitiveness that will be followed by an inflation rise. However, even through a price increase, the LOOP gap reaches positive values indicating an increase in importers losses. This means that importers are bearing the costs of depreciation due to the high rigidity of import prices. Due to the high rigidity in the imported goods sector, the response of imported inflation is hump-shaped and lasts for much longer. To stabilize inflation, the interest rate is increased to reach steady state. For 
the case of an early adoption of a post-transition regime (magenta dot-dashed line in Figure (7)), abandoning interest rate smoothing can be seen as a fast decrease in the interest rate.

\section{Macroeconomic stability}

In the previous section we discussed differences in impulse responses induced by an announcement of change in the monetary policy regime. These responses mostly differ in the extent of the deviations. Therefore, we focus on the volatilities of the key macroeconomic variables (inflation, output gap, and the exchange rate change) under the alternative monetary regimes described by rules (29) and (31), in this section.

Focus on macroeconomic stability was used as the standard approach in the early literature on monetary policies evaluations. As the main advantage of this approach is the independence from the utility-loss function specification. However, we believe it can still offer interesting comparisons, as presented by Cuche-Curti, Dellas, and Natal (2008), or by Collard and Dellas (2002).

As mentioned in the introductory section, we restrict our analysis to four parameterizations of the general rules (29), and (31) respectively in the model that allows the announcement of change of the monetary regime. These four regimes represent the standard classes of monetary policies. Therefore, we decided to study the following four regimes: strict CPI inflation targeting (SIT); strict change in the exchange rate targeting (SET); the standard Taylor rule (STR); and a rule where inflation and change in the exchange rate is targeted (STRET).

Table (2) summarizes the calibration of the monetary policy rules (29) and (31) for the aforementioned regimes. To set up the rest of the structural parameters, we use the values estimated in the previous section.

First, to get the initial values (pre-transition) for recursive computation of variances over the transition period, we use these regimes in the model without a pos- 


\begin{tabular}{l|llll}
\hline Regime & Parameters & & & \\
\hline \hline Strict IT & $\rho_{i}=0.6$ & $\rho^{\pi}=2.0$ & $\rho^{y}=0.0$ & $\rho^{e}=0.0$ \\
Strict ET & $\rho_{i}=0.6$ & $\rho^{\pi}=0.0$ & $\rho^{y}=0.0$ & $\rho^{e}=1.0$ \\
Standard TR & $\rho_{i}=0.6$ & $\rho^{\pi}=1.5$ & $\rho^{y}=0.4$ & $\rho^{e}=0.0$ \\
STRET & $\rho_{i}=0.6$ & $\rho^{\pi}=1.5$ & $\rho^{y}=0.0$ & $\rho^{e}=0.1$ \\
\hline
\end{tabular}

Table 2: Regimes definition

sibility of a regime switch. Table (3) shows the resulting standard deviations (in percentage points on quarterly frequency) of variables of the interest in the four aforementioned regimes. The last column of Table (3) shows standard deviations for the post-transition regime, the regime is employed after the regime switch (30).

\begin{tabular}{l|ccccc}
\hline Variable & Strict IT & Strict ET & Stand. TR & STRET & Post-transition \\
\hline \hline Output & 1.04 & 1.06 & 1.00 & 1.04 & 1.06 \\
Nominal int. rate & 0.82 & 0.95 & 0.83 & 0.85 & 1.01 \\
Real ex. rate & 4.19 & 4.10 & 4.19 & 4.16 & 4.19 \\
Terms of trade & 6.74 & 6.69 & 6.94 & 6.73 & 6.84 \\
CPI inflation & 1.98 & 1.31 & 2.23 & 1.81 & 1.41 \\
Domestic inflation & 2.83 & 1.98 & 3.17 & 2.60 & 1.99 \\
Imported inflation & 1.22 & 0.53 & 1.37 & 1.08 & 0.87 \\
LOP gap & 2.63 & 0.94 & 2.80 & 2.27 & 0.78 \\
Marginal costs & 0.79 & 0.48 & 0.87 & 0.71 & 0.43 \\
$\Delta e$ & 2.87 & 0.86 & 3.04 & 2.45 & 0.81 \\
\hline \hline
\end{tabular}

Table 3: Standard deviations: Model without regime switch

The standard deviations presented in the Table (3) reflect the nature of the used regimes. Low volatility of change in the nominal exchange rate is delivered by the SET and the post-transition regimes, where the monetary policy rule focuses on offsetting these changes. This is reflected by a higher volatility of the nominal interest rate and output. Surprisingly, for our choice parameters, the strict IT regime is not able to deliver the lowest value of inflation volatility. However, the high volatility of $\Delta e$ and inflation signal that the SIT regime shows a trade-off between these volatilities and the nominal interest rate.

The focus of our analysis is the volatility of macroeconomic variables over the transition from the initial regime towards the post-transition regime. To compute the variance of variables over the transition between the announcement of the monetary regime switch and the actual regime switch, we evaluate the information shocks and 
evaluate the system for the announced regime switch.

Figure (8) shows the development standard deviations for regimes summarized in Table (2) in the case of a transition 8 periods long. In this figure, period 1 is the initial period, and values refer to the standard deviations in model without a regime change. The period number 2 is the first period of transition and is followed by 8 periods of a transition regime. So, period 9 is the last period of transition, and the post-transition regime is employed starting from period 10 . In here, the motivation for the choice of 8 periods is the usual length of accessing countries operating under the ERM II. In all figures showing variance, the black dotted line represents development under SIT regime, the magenta solid line is for SET, the STR is represented by red dash-dotted line, and the STRET by blue dashed line.

The evolution of standard deviations, shown in Figure (8), confirms that by construction, inflation targeting regimes deliver the low volatility of the CPI inflation over the transition. These regimes also deliver the low variance for the domestic component of inflation and in the late periods of transition for the foreign inflation component, too. We find this consistent with the observed trade-off between inflation and the nominal exchange rate volatility.

Our computations show that the nominal interest rate volatility culminates in the last period of the transition for any of the considered regimes. This peak is consistent with foreseen deviations in the changes of the nominal exchange rate and with the reaction of the monetary authority that tries to eliminate them before the regime switch. This is also consistent with a hike in volatility of change in the nominal exchange rate in the late periods of the transition regime.

Due to the volatility trade-offs between variables, a simple comparison of volatilities does not straightforwardly identify regime that does deliver the lowest welfare loss. Therefore, we want to create a ranking among the considered representative monetary regimes in order to find the best performing one. First, for the purpose of monetary regime comparison, we use the traditional form [e.g. as in Santacreu 
(2005)] the loss function of monetary authority:

$$
L_{t}=\tau \operatorname{Var}\left(\pi_{t}\right)+(1-\tau) \operatorname{Var}\left(y_{t}\right)+\frac{\tau}{4} \operatorname{Var}\left(\Delta i_{t}\right),
$$

where $\tau \in<0,1>$ is the weight on inflation stabilization. To compute loss function, we set $\tau=0.77$ to reflect the ratio of inflation to output stabilization in the estimated monetary policy rule. In our experiment, we evaluate loss function for various dates of the regime change.

The evolution of the instantaneous loss function values given by (37) for the aforementioned regimes are plotted in Table (8). In these plots, the first period plotted is the first period of transition regime. These plots suggests the the SIT regime delivers the lowest values of loss at the end of the transition regime. The highest loss is delivered by the SET regime.

However, the form of loss function as mentioned by Santacreu (2005) does not reflect the changes in the volatility of the exchange rate. Therefore, the following alternative form of the loss function is used:

$$
L_{t}^{a}=\tau \operatorname{Var}\left(\pi_{t}\right)+(1-\tau) \operatorname{Var}\left(y_{t}\right)+\frac{\tau}{4} \operatorname{Var}\left(\Delta i_{t}\right)+\frac{\tau}{4} \operatorname{Var}\left(\Delta e_{t}\right)
$$

The evolution of $L_{t}^{a}$ is presented in Table (9). These plots show that focus on exchange rate stabilization affects teh ordering of the considered regimes.

To identify the best performing regime over the transition period, we use the sum of instantaneous losses discounted by a factor of $\beta$ over the 40 periods for both forms of loss function. The sums of welfare losses for a given length of transition period are presented in Tables (8) and (9).

For the form given by equation (37), the SIT regime is identified as the best performing regime (delivering the lowest values of welfare loss) for all lengths of the transition period. When the alternative form of loss function with non-zero weight on exchange rate targeting is used, the choice of the optimal regime depends on the transition period length. For a transition period shorter than 8 periods, the SIT 
regime is the best performing regime. For transition periods longer than 8 periods the STRET regime is the optimal regime.

Figure (10) shows the initial change in standard deviations as a percentage change of standard deviation in comparison with the standard deviation in the model without the possibility of a regime switch. In this figure, the initial change is a function of the number of periods to regime switch. As it can be observed, a short period of transition leads to a substantial increase in the volatility of imported inflation, the nominal interest rate. This can be explained by a strong reaction of monetary policy needed to suppress deviations over the short period.

The extent of initial changes in the standard deviation of all variables do not vary much for transition periods that are longer than 12 periods. Therefore, we believe that our results of the welfare analysis will not show a significant change when the length of transition is extended. This result can be justified by the impulse response functions (Figures (1)-(4)) which show that there are significant deviations from the steady state after 12 periods only for a very persistent shock.

Figure (10) also reveals that the output volatility is almost unaffected by the choice of the transition length and the change originates from the transition to a model with possibility of regime switch. This is consistent with small differences in output volatility across analyzed regimes. Therefore, the changes in output volatility are not the main force driving the loss function ranking.

Further, we use the terms of trade variance to rank examined regimes. The use of this criterion is based on Gali and Monacelli's (2005) conclusion that the critical element for distinguishing a simple rule relative to the optimal policy is the excess smoothness of the terms of trade. They note that the terms of trade are more stable under an exchange rate peg than under any other policy regime. This feature is a consequence of the inability of sticky prices to compensate for the elimination of change in the nominal exchange rate. Gali and Monacelli (2005) show that the higher the terms of trade volatility, the lower the volatility of inflation and the output gap, across the considered regimes. That means that the higher the volatility of the 
terms of trade the higher, the resulting welfare score.

In this case, we compare regimes against the strict IT regime that was identified as the best performing according to the traditional loss function form. In Figure (9), we plot the difference of variance of the terms of trade between the considered regime and the SIT regime. In here, a positive value indicates an excess of volatility over the SIT regime. We observe that the strict ET regime delivers the largest amount of terms of trade volatility. According to Gali and Monacelli's (2005) conclusion, this implies the highest welfare score should be achieved for the SET regime. These results are contrary to the aforementioned results of the loss function evaluation.

\subsection{Variance decomposition}

Finally, to assess the forces that drive the business cycles under the pre-transition and post-transition regime, we report the differences in variance decomposition for the main variables of our interest in Table (4). The reported differences are computed as the difference of shock contribution (in percents) in the post-transition regime and pre-transition regime, where positive values mean an excess of contribution in the post-transition regime. Moreover, the estimated model is considered for the pretransition period.

\begin{tabular}{l|rrrrrrr}
\hline & & & \multicolumn{3}{c}{ Shocks } & & \\
Variable & $\varepsilon^{a}$ & $\varepsilon^{m}$ & $\varepsilon^{g}$ & $\varepsilon^{s}$ & $\varepsilon^{\pi}$ & $\varepsilon^{y}$ & $\varepsilon^{i}$ \\
\hline \hline$\Delta e_{t}$ & -3.8 & -11.3 & -64.8 & -17.9 & 5.0 & 78.2 & 14.6 \\
$i_{t}$ & -10.4 & -2.2 & -6.7 & -73.1 & 4.1 & 75.4 & 12.9 \\
$m c_{t}$ & -12.3 & -29.1 & 91.6 & -44.4 & 0.5 & -3.5 & -2.9 \\
$\pi_{t}$ & -15.2 & -26.6 & 82.7 & -43.3 & 1.6 & 2.7 & -2.0 \\
$p i_{t}^{F}$ & -9.8 & -9.7 & -61.2 & -17.7 & 14.3 & 78.0 & 6.0 \\
$p i_{t}^{H}$ & -11.2 & -22.3 & 70.1 & -35.5 & 1.0 & -0.2 & -1.9 \\
$\psi_{t}^{F}$ & -3.6 & -11.0 & -66.5 & -17.6 & 63.9 & 14.4 & 20.4 \\
$y_{t}^{F}$ & 2.3 & -1.2 & 0.8 & -1.9 & 0.1 & -0.1 & -0.1 \\
\hline \hline
\end{tabular}

Table 4: Variance decomposition: Difference in the post-transition and pretransition

The negative change in the contribution of a monetary policy shock and risk premium originate from the design of our experiment when these shocks are elimi- 
nated in the post-transition model. The preference shock $\varepsilon^{g}$ becomes the dominant source of macroeconomic volatility under the post-transition regime. So off-setting the nominal exchange rate changes makes the Czech Republic significantly more vulnerable to the domestic preference shock that acts as a demand shock in the estimated model.

As the exchange rate becomes less volatile, the foreign shock become an important source of macroeconomic volatility. The source of volatility in the LOOP gap $\psi_{t}^{F}$ moves from the domestic preference shock towards mostly a foreign inflation shock indicating that profits of importers are fully dependent on the foreign economy under the post-transition regime. Similarly, as the role of the interest rate is to prevent exchange rate movements more than $90 \%$ of its volatility originates in the foreign economy. We believe that these changes reflect the structural change of an economy when the exchange rate stability is the focus of the monetary authority.

\section{Conclusions}

The motivation for this work was to analyze whether the announcement of a monetary regime switch in a small, open economy can lead to gradual changes in macroeconomic volatility. Therefore, we presented an model that allows us to describe the behavior of an economy when the change of monetary policy is expected. Moreover, we focus on the behavior of a small open economy over the transition period, when the focus of the monetary policy regime switches to exchange rate stability.

First, the parameters of the model without the possibility of a regime switch are estimated via the Bayesian method using data on the Czech Republic. We find the values of the estimated parameters consistent with the experience of the Czech economy.

Further, we extend the estimated simple small open economy model with an information buffer. This extension leads to the non-linear model capable of capturing announced monetary policy regime as a realization of the information shocks. The 
extended model is solved using the second-order approximation. The announcement of the regime switch takes the form of the information shocks. The considered model becomes linear after the information shocks are realized.

For our analysis, we compute impulse response functions under different (easily implementable) monetary policy regimes in order to identify the differences in behavior of the economy, in the case of the announced regime switch. Then the ad-hoc loss functions are computed in order to create rankings among these regimes.

By a analysis of conditional volatility, we are able to identify changes in the macroeconomic volatility over the transition period. When the regimes are ranked according to the excess volatility, as the best performing is identified, the regime targeting exchange rate changes. When the loss function approach is used, the regime strictly targeting CPI inflation is identified as the best performing when exchange rate volatility is not a concern of the monetary authority. However, when also the exchange rate volatility is included into the welfare of the monetary authority, a small portion of a change in the exchange rate targeting delivers a lower loss over long transition periods.

The findings reported above have interesting implications for the conduct of monetary policy in a transition regime. First, pursuing a regime of exchange rate stability over the transition period does deliver a higher welfare loss when preferences of the monetary authority still favor stability of domestic inflation and output. However, better results can be obtained by abandoning the focus on output stability. Second, the relative importance of domestic shocks for macroeconomic volatility is decreased as foreign shocks become very important. Third, depending on the goals of the monetary authority, the optimal regime can vary with respect to the transition period length.

\section{References}

An, Sungbae, and Frank Schorfheide. 2007. "Bayesian Analysis of DSGE Models." Econometric Reviews 26 (2-4): 113-172. 
Carlstrom, Charles T., and Timothy S. Fuerst. 2000. "Forward-looking versus backward-looking Taylor rules." Technical Report.

Collard, Fabrice, and Harris Dellas. 2002. "Exchange rate systems and macroeconomic stability." Journal of Monetary Economics 49 (3): 571-599. available at http://ideas.repec.org/a/eee/moneco/v49y2002i3p571-599.html.

Collard, Fabrice, and Michel Juillard. 2001a. "Accuracy of stochastic perturbation methods: The case of asset pricing models." Journal of Economic Dynamics and Control 25 (6-7): 979-999. available at http://ideas.repec.org/a/eee/dyncon/v25y2001i6-7p979-999.html.

- 2001b. "A Higher-Order Taylor Expansion Approach to Simulation of Stochastic Forward-Looking Models with an Application to a Nonlinear Phillips Curve Model." Computational Economics 17 (2-3): 125-39. available at http://ideas.repec.org/a/kap/compec/v17y2001i2-3p125-39.html.

Cuche-Curti, Nicolas A., Harris Dellas, and Jean-Marc Natal. 2008. "Inflation Targeting in a Small Open Economy." International Finance 11 (1): 1-18 (05).

Dellas, Harris, and G. S. Tavlas. 2003, January. "Wage rigidity and monetary union." CEPR Discussion Papers 4229, C.E.P.R. Discussion Papers.

Farmer, Roger E.A., Daniel F. Waggoner, and Tao Zha. 2007, March. "Understanding the New-Keynesian Model when Monetary Policy Switches Regimes." Working paper 12965, National Bureau of Economic Research.

Fuhrer, Jeffrey C. 2000. "Habit Formation in Consumption and Its Implications for Monetary-Policy Models." American Economic Review 90 (3): 367-390 (June).

Gali, Jordi, and Tommaso Monacelli. 2002, April. "Monetary Policy and Exchange Rate Volatility in a Small Open Economy." NBER Working Papers 8905, National Bureau of Economic Research, Inc. available at http://ideas.repec.org/p/nbr/nberwo/8905.html.

- 2005. "Monetary Policy and Exchange Rate Volatility in a Small Open Economy." Review of Economic Studies 72 (3): 707-734.

Ireland, Peter N. 2004. "A method for taking models to the data." Journal of Economic Dynamics and Control 28 (6): 1205-1226 (March). available at http://ideas.repec.org/a/eee/dyncon/v28y2004i6p1205-1226.html.

Juillard, Michel. 1996. "Dynare : a program for the resolution and simulation of dynamic models with forward variables through the use of a relaxation algorithm." Cepremap working papers (couverture orange) 9602, CEPREMAP. available at http://ideas.repec.org/p/cpm/cepmap/9602.html.

Justiniano, Alejandro, and Bruce Preston. 2004, September. "Small Open Economy DSGE Models: Specification, Estimation and Model Fit." unpublised manuscript.

Kameník, Ondra. 2007, July. "DSGE Models with Dynare++. A Tutorial." Technical Report v. 1.3.5. available at http://www.cepremap.cnrs.fr/dynare/.

Kollmann, Robert. 2002, March. "Monetary Policy Rules in the Open Economy: Effects on Welfare and Business Cycles." Cepr discussion papers 3279, C.E.P.R. Discussion Papers. available at http://ideas.repec.org/p/cpr/ceprdp/3279.html. 
Lubik, Thomas, and Frank Schorfheide. 2003, November. "Do Central Banks Respond to Exchange Rate Movements? A Structural Investigation." Economics working paper archive 505, The Johns Hopkins University,Department of Economics. available at http://ideas.repec.org/p/jhu/papers/505.html.

- 2005, May. "A Bayesian Look at New Open Economy Macroeconomics." Economics working paper archive 521, The Johns Hopkins University,Department of Economics. available at http://ideas.repec.org/p/jhu/papers/521.html.

Lubik, Thomas A. 2005, December. "A Simple, Structural, and Empirical Model of the Antipodean Transmission Mechanism." Reserve bank of new zealand discussion paper series DP2005/06, Reserve Bank of New Zealand. available at http://ideas.repec.org/p/nzb/nzbdps/2005-06.html.

Monacelli, Tommaso. 2005. "Monetary policy in a low pass-through environment." Journal of Money, Credit, and Banking 37 (6): 1047-1066 (December).

Natalucci, Fabio M., and Federico Ravenna. 2002. "The road to adopting the euro: monetary policy and exchange rate regimes in EU candidate countries." Technical Report.

—. 2003, October. "The Road to Adopting the Euro: Monetary Policies and Exchange Rate Regimes in EU Accession Countries." mimeo, Board of Governors of the Federal Reserve System (U.S.). available at http://ideas.repec.org/p/fip/fedgif/741.html.

Santacreu, Ana Maria. 2005, October. "Reaction functions in a small open economy: What role for non-traded inflation?" Reserve bank of new zealand discussion paper series DP2005/04, Reserve Bank of New Zealand. available at http://ideas.repec.org/p/nzb/nzbdps/2005-04.html.

Smets, Frank, and Raf Wouters. 2003. "An Estimated Dynamic Stochastic General Equilibrium Model of the Euro Area." Journal of the European Economic Association 1 (5): 1123-1175. available at http://ideas.repec.org/a/tpr/jeurec/v1y2003i5p1123-1175.html.

Walsh, Carl E. 2003, May. Monetary Theory and Policy : Second Edition. The MIT Press. 


\section{A Estimation}

\section{A.1 Data description}

All data in estimation are from the Czech National Bank database. Series are seasonally adjusted. All observed series are measured with quarterly frequency. Series are in logs; therefore they can be interpreted as the percentage deviations from steady state levels,

- Domestic output growth $\left(\Delta G D P_{t}\right)$ is the HP de-trended annualized logarithm of real GDP growth.

- Domestic CPI inflation deviation $\left(P I_{t}\right)$ is the HP de-trended annualized quarterly growth rate of the logarithm of the consumer price index (CPI).

- Nominal interest rate $\left(R S_{t}\right)$ is the HP de-trended annualized quarterly value of the 3-month PRIBOR.

- Change in the nominal exchange rate $\left(\Delta E_{t}\right)$ is the HP de-trended quarterly value of the nominal CZK-Euro exchange rate of.

- Real exchange rate $\left(Q_{t}\right)$ is the HP de-trended quarterly value of the real exchange rate.

- Foreign output gap $\left(G D P_{t}^{*}\right)$ is the real GDI gap for an effective Eurozone created by the use of the export values weights and de-trended by the Kálmán filter.

- Foreign real interest rate $\left(R S_{t}^{*}\right)$ is the HP de-trended annualized quarterly value of the 3-month EURIBOR.

- Foreign inflation $\left(P I_{t}^{*}\right)$ is the HP de-trended annualized quarterly growth rate in the log of consumer price index for the effective Eurozone (export weights).

All series used for estimation are covering the period from the first quarter of 1998 to the second quarter of 2007.

\section{A.2 Measurement block}

For our estimation the following measurement block is used to relate model variables to observed time series data:

$$
\begin{aligned}
\Delta G D P_{t} & =4 *\left(y_{t}-y_{t-1}+\varepsilon_{t}^{a}-\varepsilon_{t-1}^{a}\right)+\varepsilon_{t}^{G D P} \\
P I_{t} & =4 * \pi_{t}+\varepsilon_{t}^{P I} \\
R S_{t} & =4 * i_{t}+\varepsilon_{t}^{R S} \\
\Delta E_{t} & =4 * e+\varepsilon_{t}^{\Delta E} \\
Q_{t} & =q_{t}+\varepsilon_{t}^{Q} \\
P I_{t}^{*} & =4 * p i^{*}+\varepsilon_{t}^{P I^{*}} \\
R S_{t}^{*} & =4 * i^{*}+\varepsilon_{t}^{R S^{*}} \\
G D P_{t}^{*} & =y^{*}+\varepsilon_{t}^{G D P^{*}}
\end{aligned}
$$


where we assume that $\varepsilon_{t}^{P I}, \varepsilon_{t}^{R S}, \varepsilon_{t}^{\Delta E}, \varepsilon_{t}^{Q}, \varepsilon_{t}^{P I^{*}}, \varepsilon_{t}^{R S^{*}}, \varepsilon_{t}^{G D P^{*}}$ are independent normally distributed with zero mean. For the estimation, we assume that the standard deviations of the measurement errors are taking the following values $0.5,0.3,2.0,1.0$, $0.1,0.1,0.1$ (in the given order).

\section{A.3 Priors and Posteriors}

\begin{tabular}{l|l|lrr|rr}
\hline \multirow{2}{*}{ Variable } & Description & \multicolumn{3}{|c|}{ Prior } & \multicolumn{2}{c}{ Posterior } \\
& Distr. & Mean & s.d. & Mode & s.d. \\
$\alpha$ & Discount factor & & 0.99 & & & \\
$\eta$ & Degree of openness & Beta & 0.40 & 0.05 & 0.38 & 0.04 \\
$\delta$ & Elasticity of F-H substitution & Gamma & 1.50 & 0.50 & 1.01 & 0.36 \\
$\sigma$ & Degree of price indexation & Beta & 0.70 & 0.10 & 0.63 & 0.15 \\
$\varphi$ & Inverse elasticity of substitution & Gamma & 0.90 & 0.50 & 0.11 & 0.07 \\
$\theta_{F}$ & Inverse elasticity of labor supply & Gamma & 1.50 & 0.50 & 3.36 & 0.79 \\
$\theta_{H}$ & Calvo pricing - foreign & Beta & 0.50 & 0.10 & 0.68 & 0.08 \\
$h$ & Calvo pricing - domestic & Beta & 0.50 & 0.10 & 0.13 & 0.04 \\
$\rho_{i}$ & Degree of habit formation & Beta & 0.80 & 0.10 & 0.72 & 0.10 \\
$\rho_{\pi}$ & Interest rate smoothing & Beta & 0.50 & 0.05 & 0.58 & 0.05 \\
$\rho_{y}$ & Response to inflation & Gamma & 1.50 & 0.20 & 1.48 & 0.19 \\
$\rho_{e}$ & Response to output gap & Gamma & 0.50 & 0.10 & 0.43 & 0.08 \\
$\omega_{11}$ & Response to ex. rate change & Gamma & 0.10 & 0.05 & 0.04 & 0.02 \\
$\omega_{12}$ & Foreign VAR & Normal & 0.70 & 0.30 & 0.07 & 0.27 \\
$\omega_{13}$ & Foreign VAR & Normal & 0.00 & 0.20 & 0.08 & 0.04 \\
$\omega_{21}$ & Foreign VAR & Normal & 0.00 & 0.20 & 0.01 & 0.18 \\
$\omega_{22}$ & Foreign VAR & Normal & 0.50 & 0.30 & -0.03 & 0.25 \\
$\omega_{23}$ & Foreign VAR VAR & Normal & 0.70 & 0.20 & 0.89 & 0.08 \\
$\omega_{31}$ & Foreign VAR & Normal & -0.10 & 0.20 & -0.02 & 0.19 \\
$\omega_{32}$ & Foreign VAR & Normal & 1.50 & 0.20 & 0.22 & 0.03 \\
$\omega_{33}$ & Foreign VAR & Normal & 0.50 & 0.20 & 0.05 & 0.02 \\
$\rho_{a}$ & Technology - VAR(1) & Normal & 0.70 & 0.30 & 0.58 & 0.12 \\
$\rho_{s}$ & Ex. rate risk - VAR(1) & Beta & 0.85 & 0.10 & 0.81 & 0.13 \\
$\rho_{g}$ & Taste shock - VAR(1) & Beta & 0.85 & 0.10 & 0.67 & 0.11 \\
\hline \hline & & Beta & 0.85 & 0.10 & 0.95 & 0.05 \\
\hline
\end{tabular}

Table 5: Results from posterior parameters (parameters) 


\begin{tabular}{l|l|lcc|cc}
\hline & & \multicolumn{3}{|c|}{ Prior } & \multicolumn{2}{c}{ Posterior } \\
Variable & Description & Distribution & Mean & s.d. & Mode & s.d. \\
\hline \hline$\varepsilon^{\pi}$ & Foreign shock variance & Gamma $^{-1}$ & 0.60 & 0.50 & 0.18 & 0.02 \\
$\varepsilon^{y}$ & Foreign shock variance & Gamma $^{-1}$ & 0.30 & 0.50 & 0.31 & 0.04 \\
$\varepsilon^{i}$ & Foreign shock variance & Gamma $^{-1}$ & 0.30 & 0.50 & 0.08 & 0.01 \\
$\varepsilon^{a}$ & Domestic shock variance & Gamma $^{-1}$ & 0.80 & 0.50 & 0.21 & 0.02 \\
$\varepsilon^{m}$ & Domestic shock variance & Gamma $^{-1}$ & 0.30 & 0.10 & 0.25 & 0.07 \\
$\varepsilon^{g}$ & Domestic shock variance & Gamma $^{-1}$ & 1.50 & 0.50 & 2.53 & 0.39 \\
$\varepsilon^{s}$ & Domestic shock variance & Gamma $^{-1}$ & 1.00 & 0.50 & 0.32 & 0.04 \\
\hline \hline
\end{tabular}

Table 6: Estimation summary: Standard deviation of structural shocks
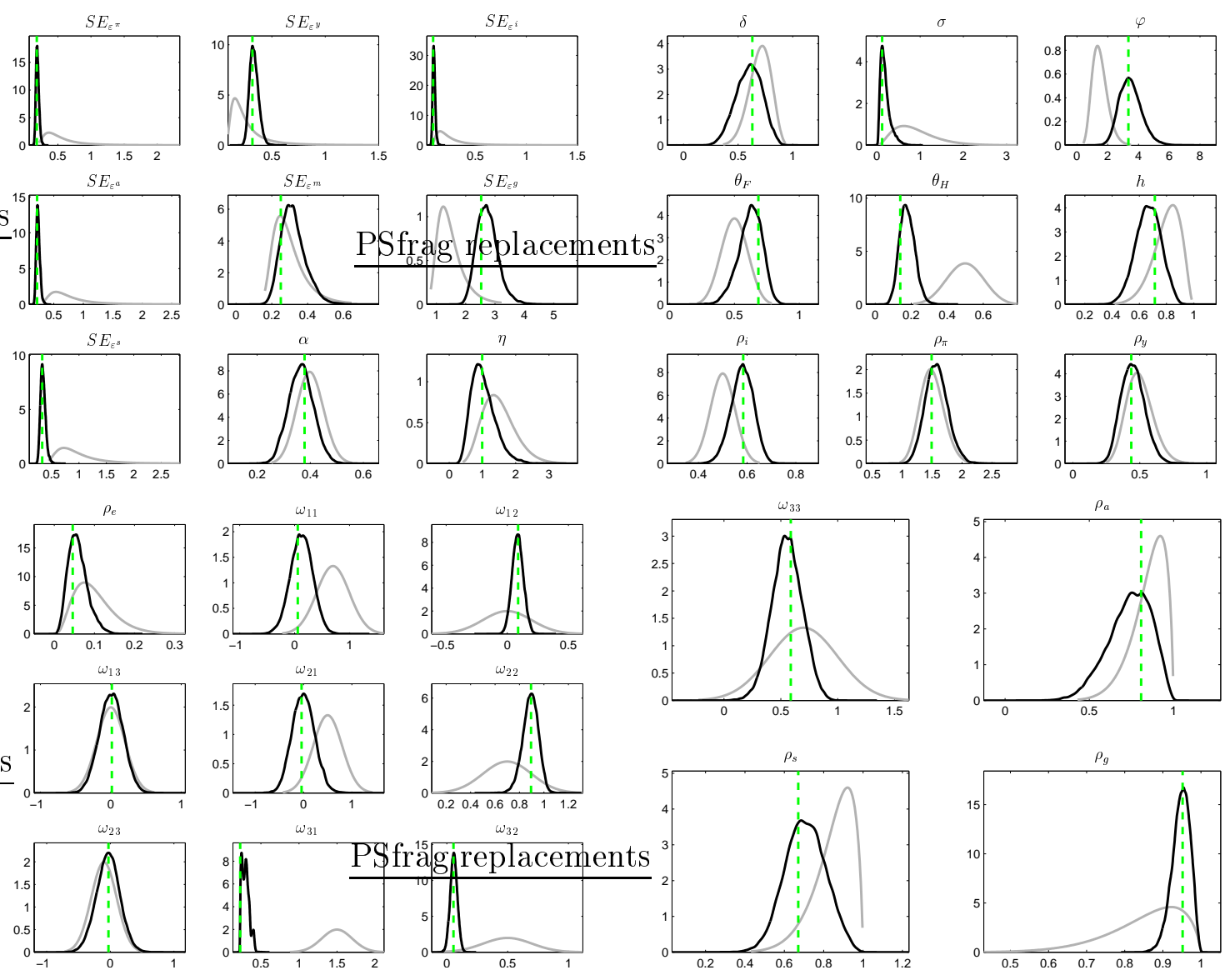

Table 7: Priors (grey line) and posterior (black line) distributions 


\section{B Impulse response functions}

In here, the following impulse responses are shown: the estimated model (solid red line); the model of regime switch in 4 (dash-doted magenta line); the 8 (dashed blue line); and the 40 (dotted black line) periods.
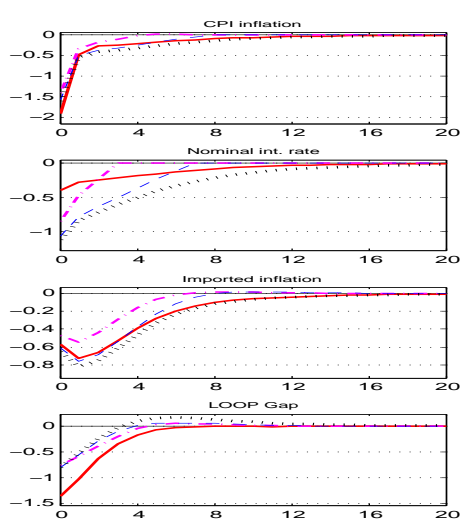
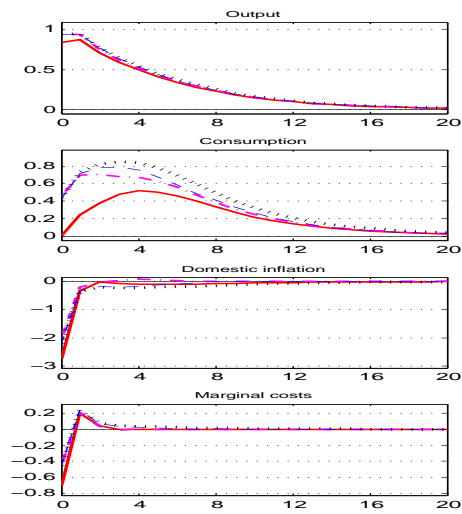
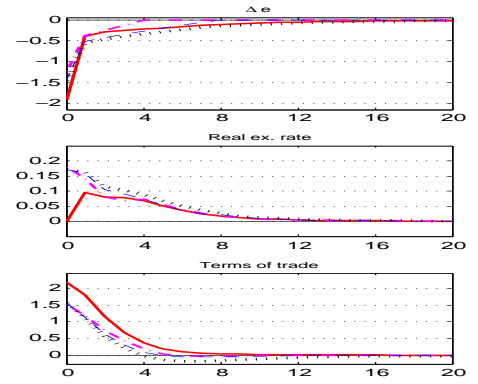

Figure 1: IRF comparison - Response to technology shock $\varepsilon^{a}$
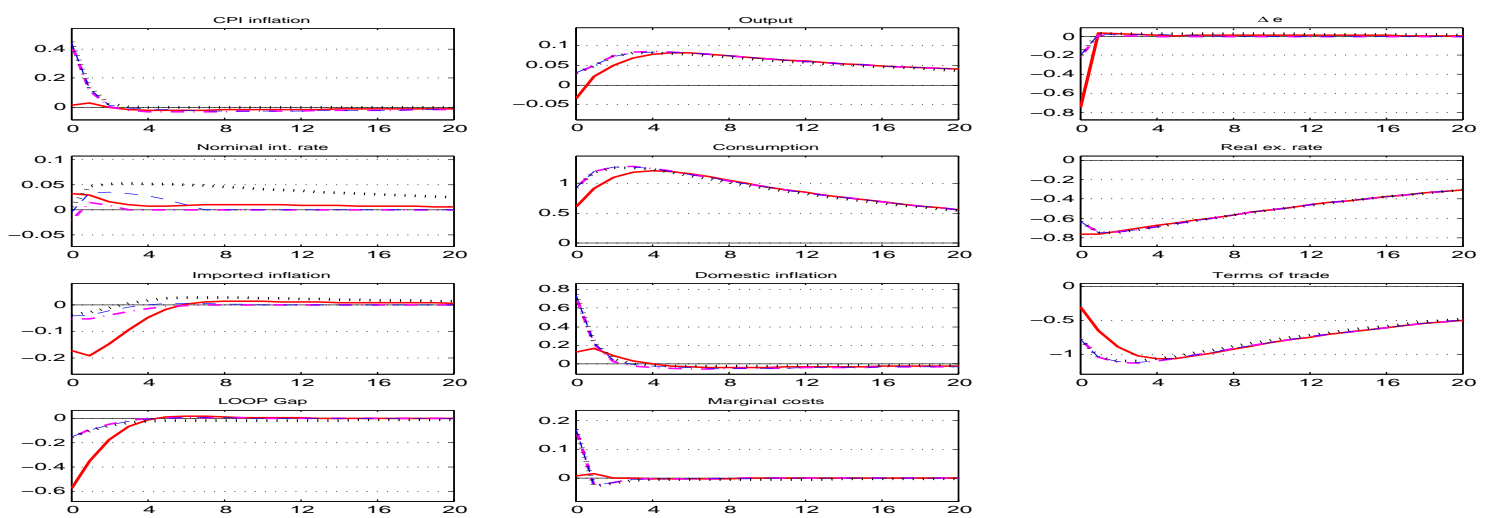

Figure 2: IRF comparison - Response to preference shock $\varepsilon^{g}$
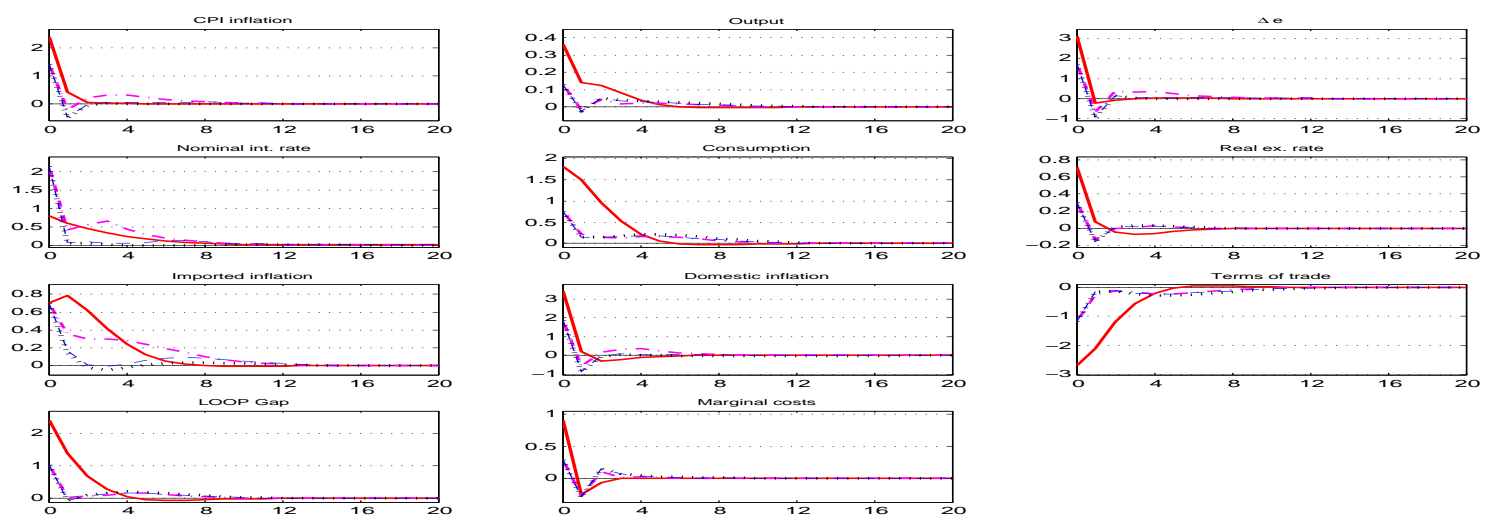

Figure 3: IRF comparison - Response to risk premium shock $\varepsilon^{s}$ 

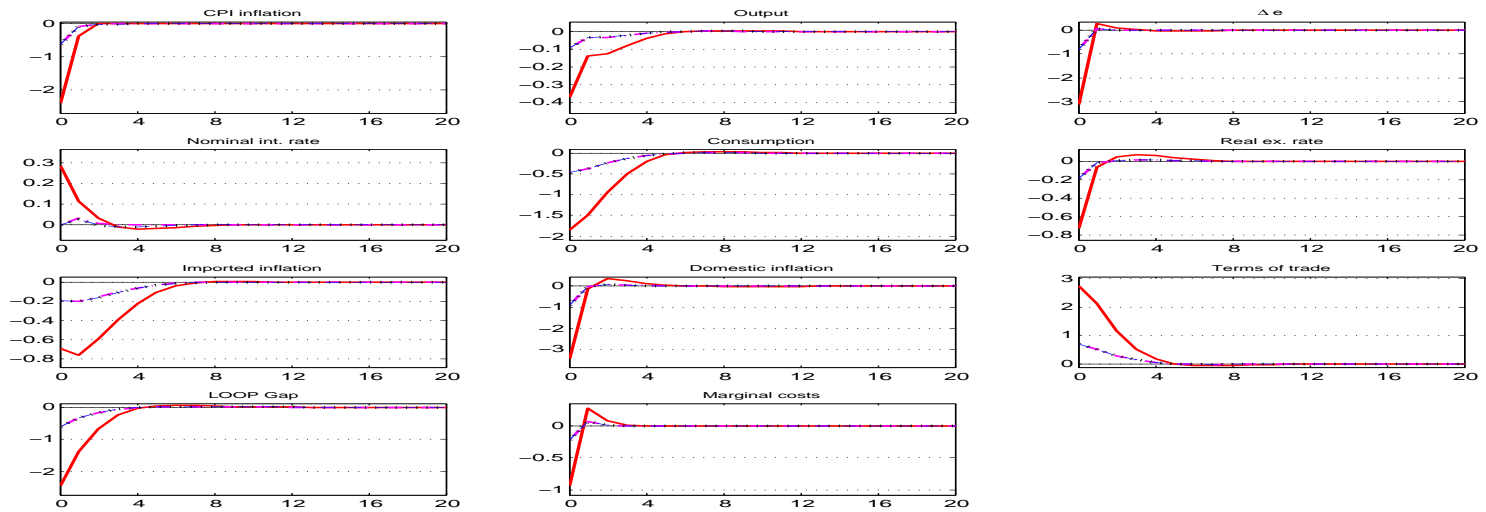

Figure 4: IRF comparison - Response to policy shock $\varepsilon^{m}$
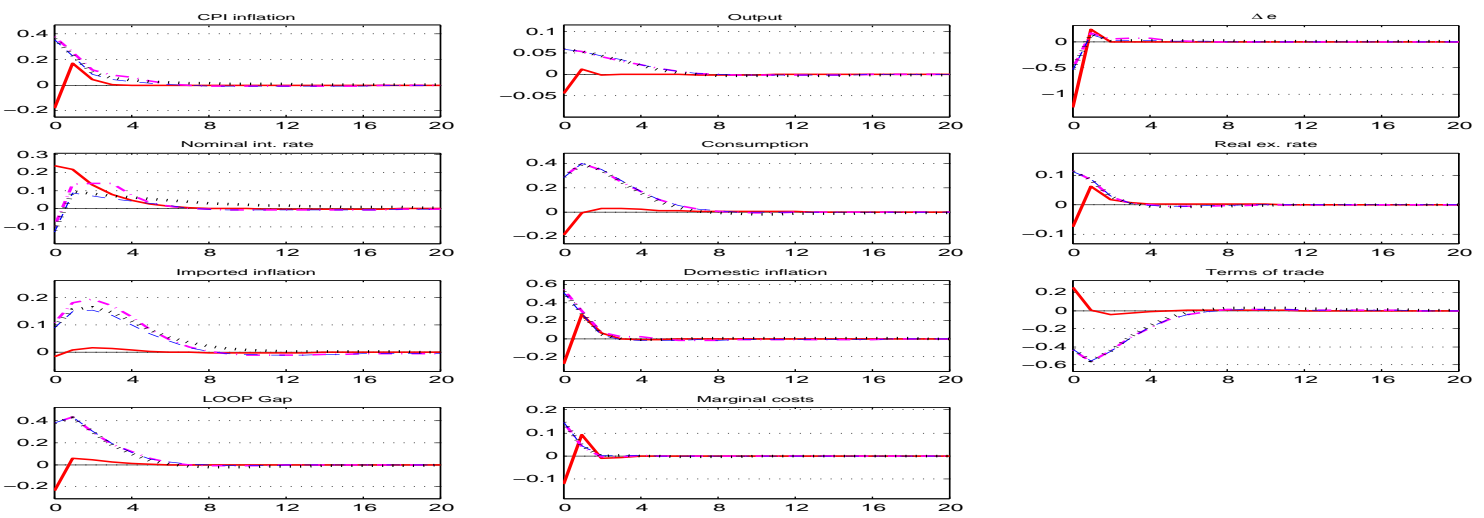

Figure 5: IRF comparison - Response to foreign inflation $\varepsilon^{\pi}$
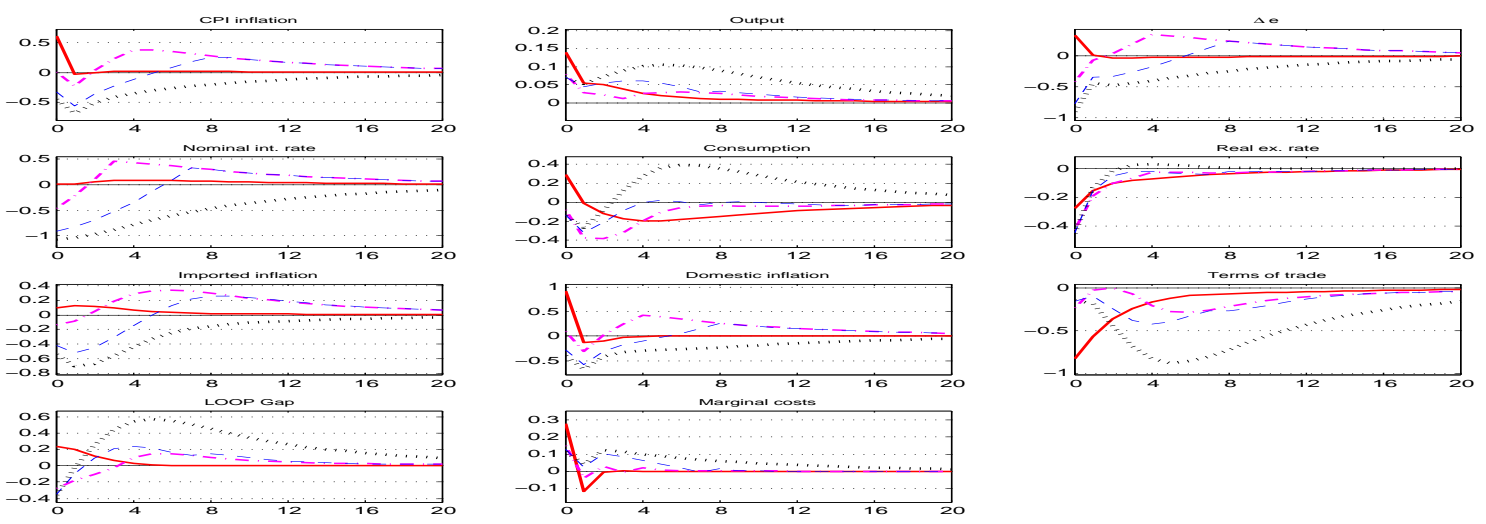

Figure 6: IRF comparison - Response to foreign output $\varepsilon^{y}$ 

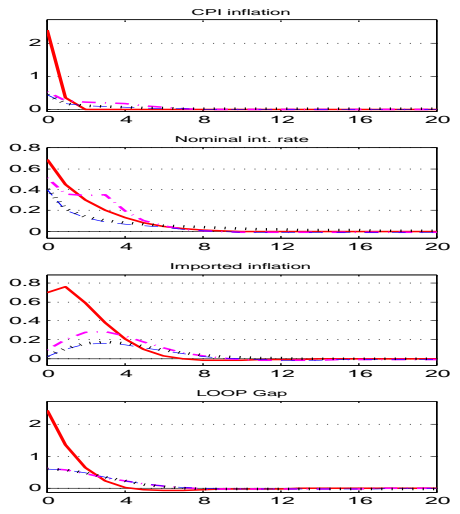
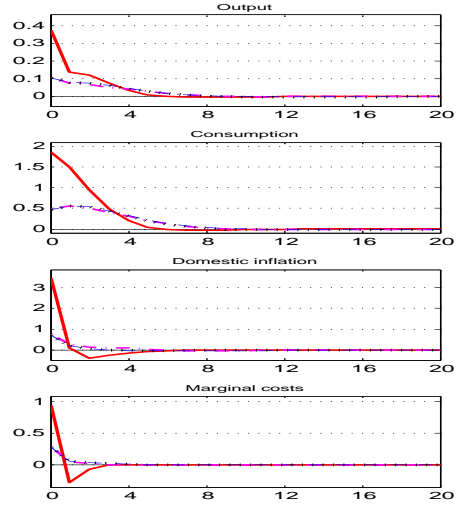
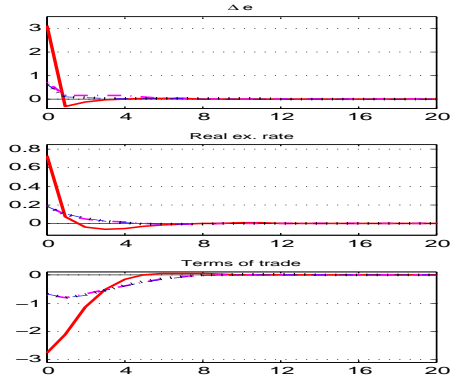

Figure 7: IRF comparison - Response to foreign interest rate $\varepsilon^{i}$

\section{Conditional standard deviations}

In here, the following evolution on variance and loss function are shown: the black dotted line represents development under SIT regime; the magenta solid line is for SET; the STR is represented by red dash-dotted line; and the STRET by blue dashed line.
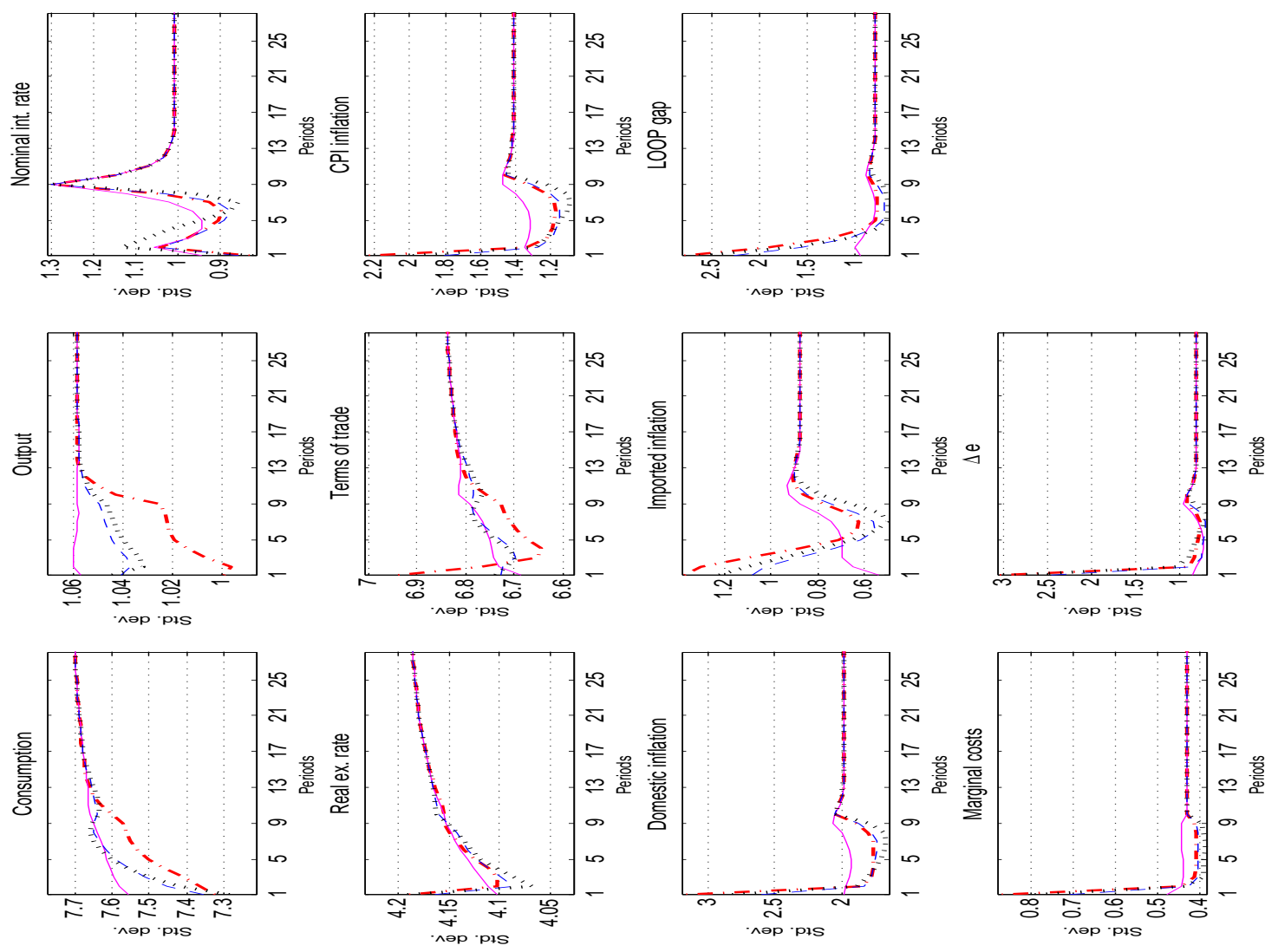

Figure 8: Conditional standard deviations: Comparison, 8 periods of transition 
2 periods
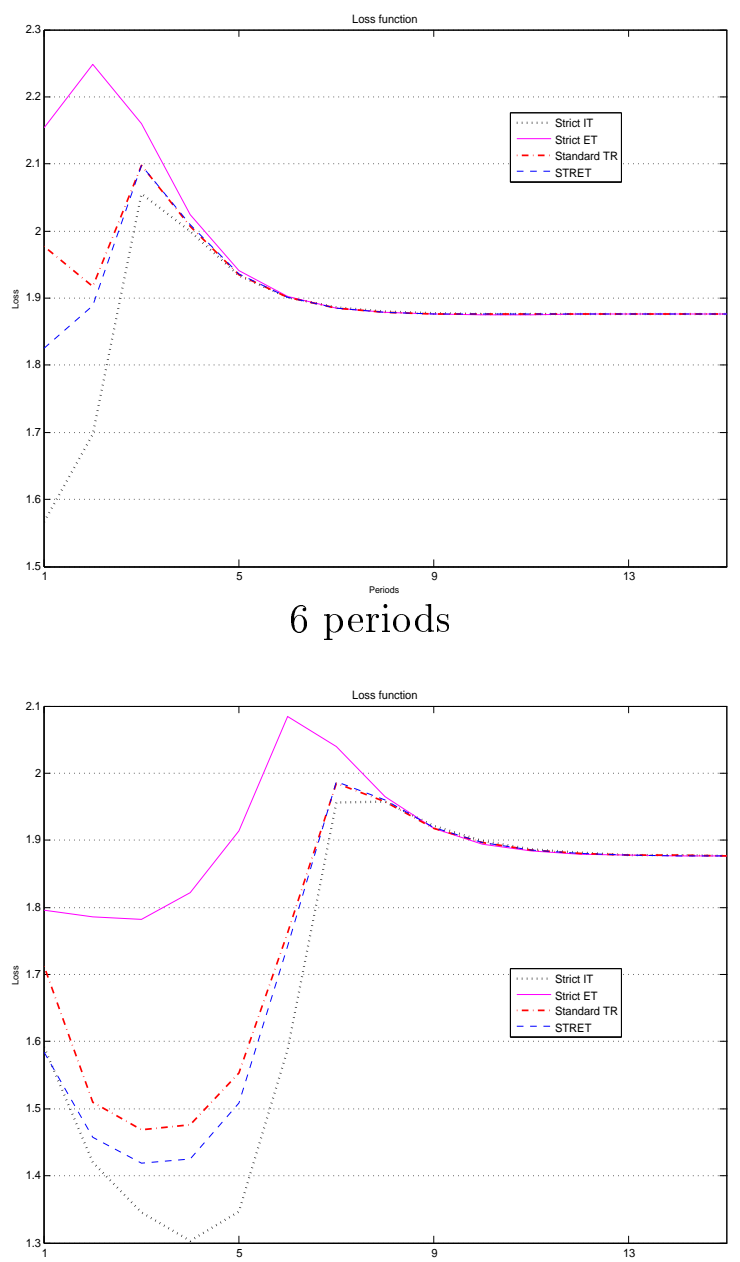

10 periods

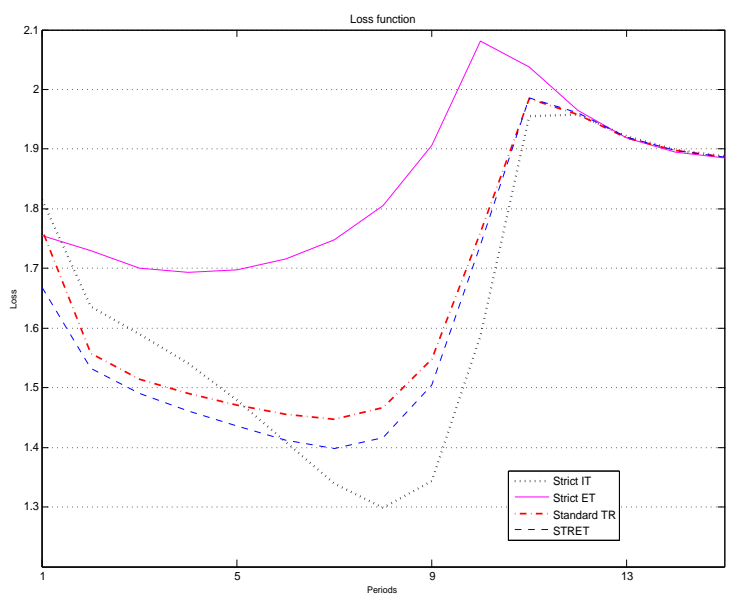

4 periods
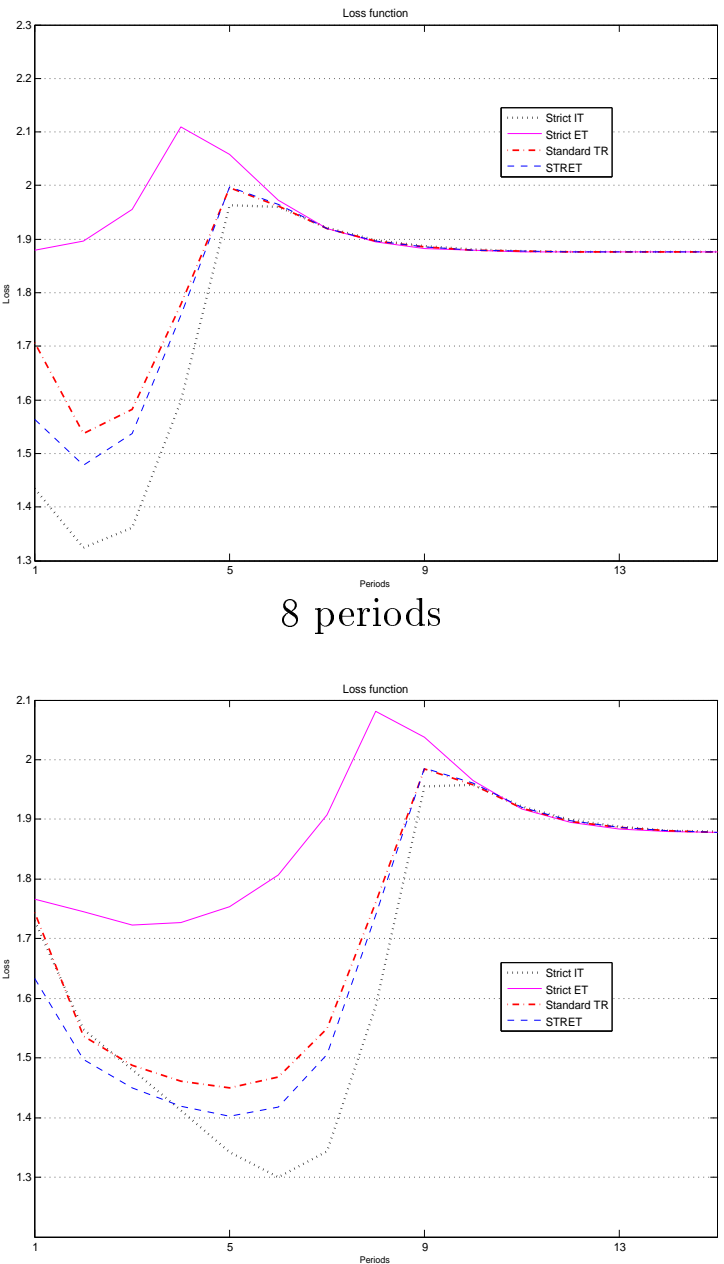

12 periods

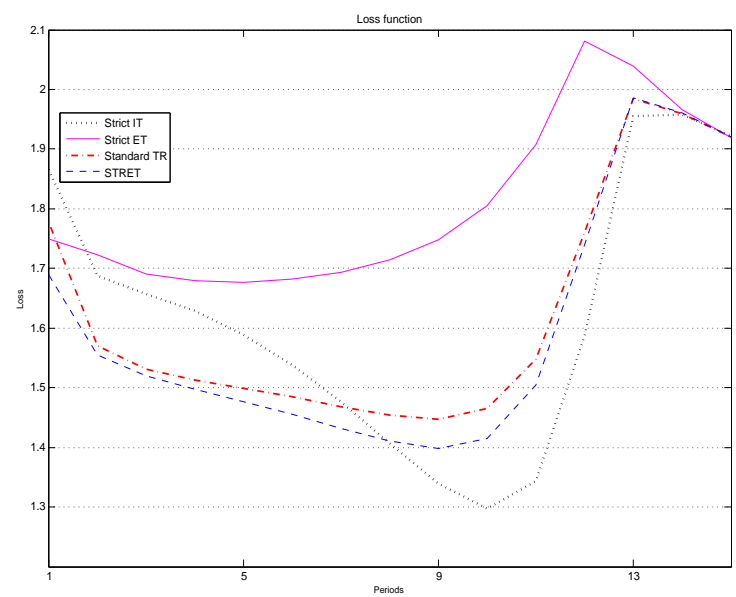

Table 8: Loss functions 
2 periods
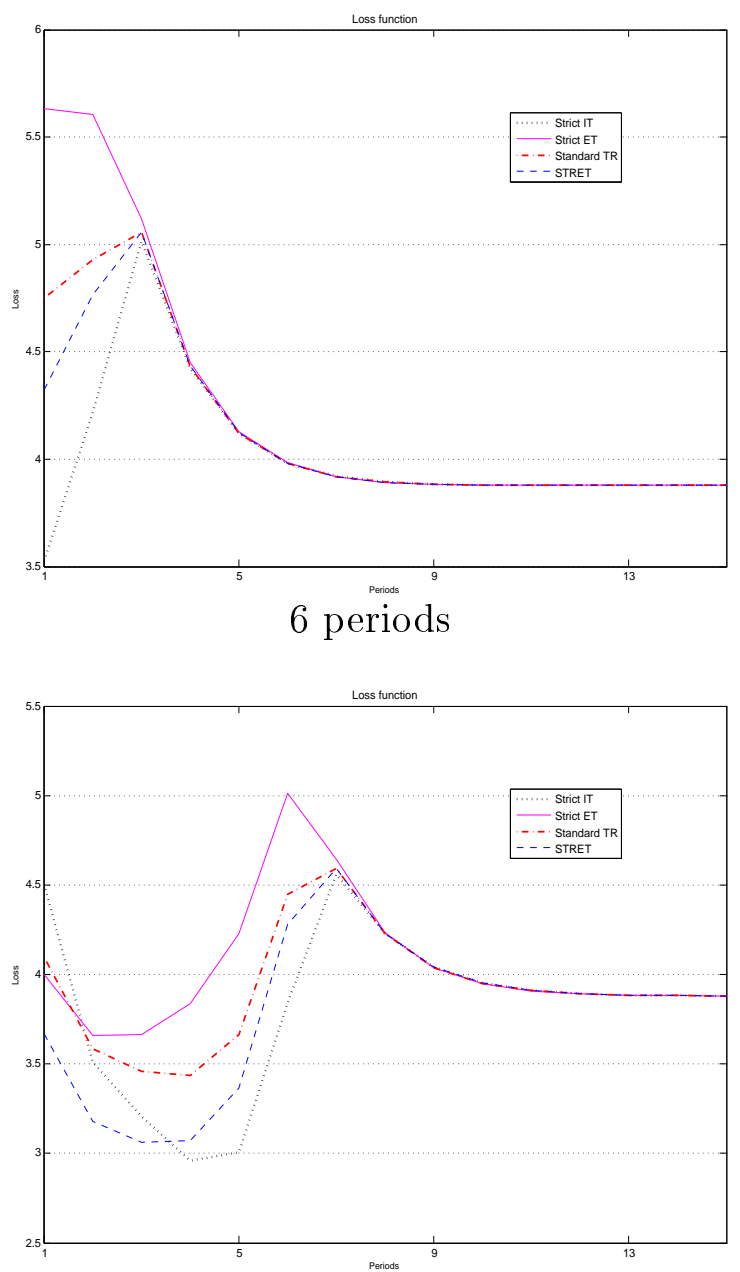

10 periods

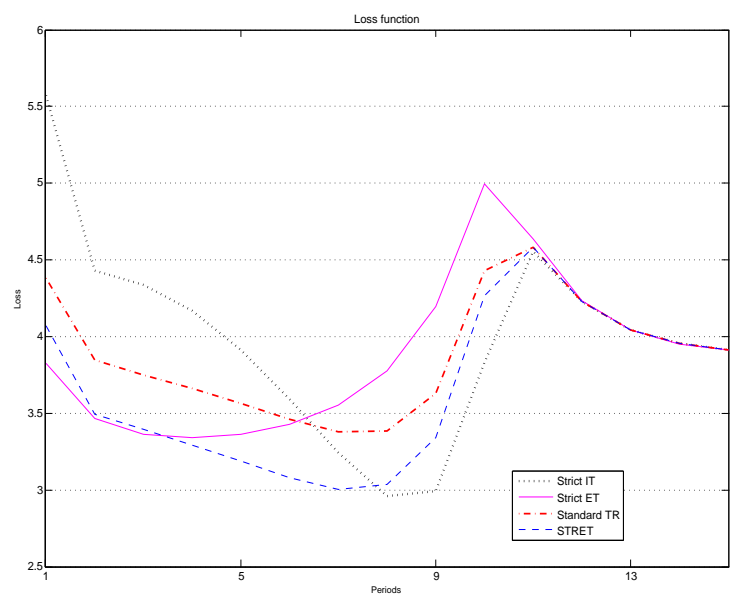

4 periods
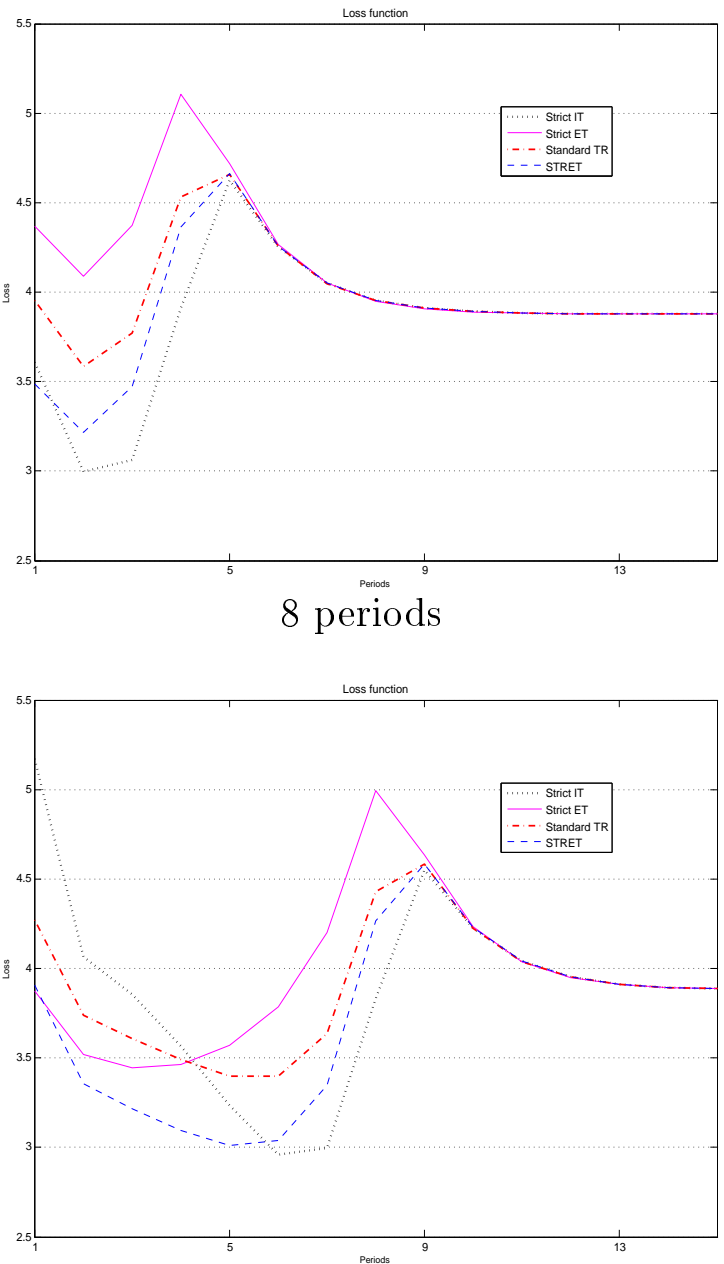

12 periods

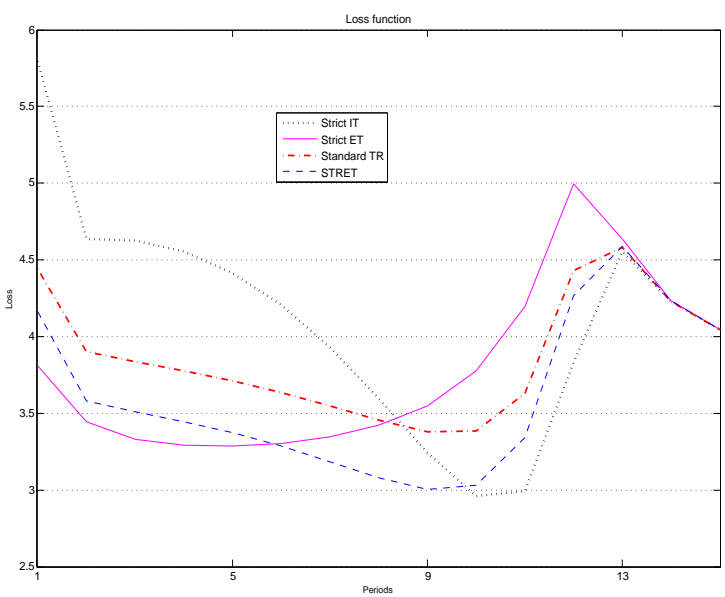

Table 9: Loss functions: Alternative form 


\begin{tabular}{c|rrrr}
\hline Period length & SIT & SET & RTR & STRET \\
\hline \hline 2 & 60.77 & 62.04 & 61.45 & 61.27 \\
4 & 59.35 & 61.53 & 60.25 & 59.99 \\
6 & 58.51 & 61.09 & 59.39 & 59.05 \\
8 & 57.96 & 60.67 & 58.65 & 58.27 \\
10 & 57.56 & 60.25 & 57.98 & 57.58 \\
12 & 57.26 & 59.84 & 57.33 & 56.93 \\
\hline \hline
\end{tabular}

Table 10: Transition length sensitivity

\begin{tabular}{c|rrrr}
\hline Period length & & \multicolumn{3}{|c}{ Regime } \\
& SIT & SET & STR & STRET \\
\hline \hline 2 & 127.85 & 131.46 & 129.83 & 129.24 \\
4 & 125.29 & 129.66 & 127.54 & 126.25 \\
6 & 124.92 & 128.22 & 126.53 & 124.51 \\
8 & 125.83 & 126.89 & 126.05 & 123.41 \\
10 & 127.44 & 125.60 & 125.83 & 122.65 \\
12 & 129.40 & 124.31 & 125.73 & 122.07 \\
\hline \hline
\end{tabular}

Table 11: Transition length sensitivity: Alternative form

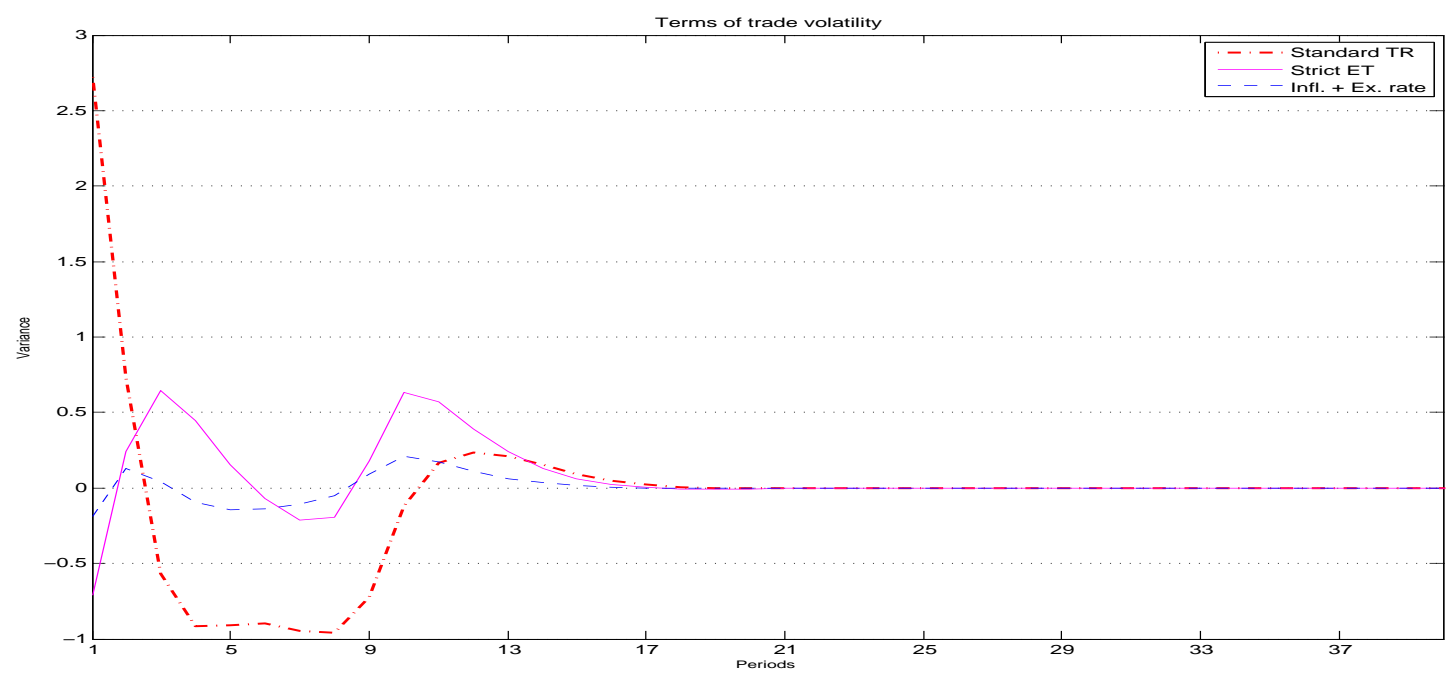

Figure 9: Terms of trade variance: Difference from strict IT 

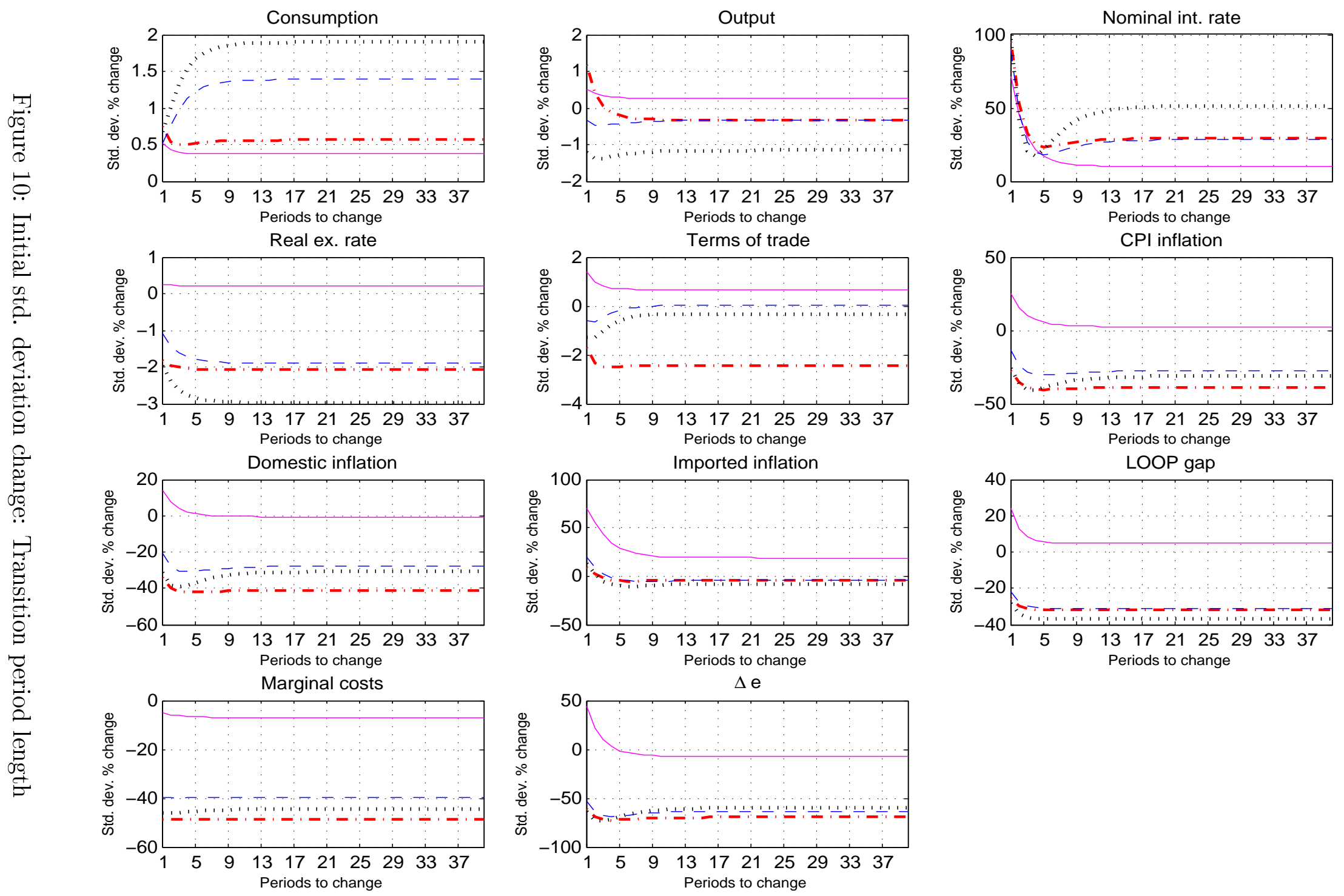

Periods to change 
Individual researchers, as well as the on-line and printed versions of the CERGE-EI Working Papers (including their dissemination) were supported from the following institutional grants:

- Center of Advanced Political Economy Research [Centrum pro pokročilá politickoekonomická studia], No. LC542, (2005-2009),

- Economic Aspects of EU and EMU Entry [Ekonomické aspekty vstupu do Evropské unie a Evropské měnové unie], No. AVOZ70850503, (2005-2010);

- Economic Impact of European Integration on the Czech Republic [Ekonomické dopady evropské integrace na ČR], No. MSM0021620846, (2005-2011);

Specific research support and/or other grants the researchers/publications benefited from are acknowledged at the beginning of the Paper.

(c) František Brázdik, Juraj Antal, 2008

All rights reserved. No part of this publication may be reproduced, stored in a retrieval system or transmitted in any form or by any means, electronic, mechanical or photocopying, recording, or otherwise without the prior permission of the publisher.

Published by

Charles University in Prague, Center for Economic Research and Graduate Education (CERGE) and

Economics Institute ASCR, v. v. i. (EI)

CERGE-El, Politických vězňů 7, 11121 Prague 1, tel.: +420 224005 153, Czech Republic.

Printed by CERGE-EI, Prague

Subscription: CERGE-EI homepage: http://www.cerge-ei.cz

Editors: Directors of CERGE and EI

Managing editors: Deputy Directors for Research of CERGE and EI

ISSN 1211-3298

ISBN 978-80-7343-168-6 (Univerzita Karlova. Centrum pro ekonomický výzkum

a doktorské studium)

ISBN 978-80-7344-157-9 (Národohospodářský ústav AV ČR, v. v. i.) 
CERGE-EI

P.O.BOX 882

Politických vězňů 7

11121 Praha 1

Czech Republic http://www.cerge-ei.cz 